\title{
KUTATÁS
}

\author{
PAPP JÚLIA
}

\section{„...A NŐKET SEHOLSEM LÁTJUK VALAMI VÉRENGZŐ FOGLALKOZÁSBAN...”}

\author{
SZÉKELY BERTALAN EGRI NŐK CÍMÛ́ FESTMÉNYÉNEK TÖRTÉNETI FORRÁSAI
}

Az 1552. évi török ostrom idején harcoló vagy a harcosoknak segítő egri asszonyok történeti, irodalmi és képzőmúvészeti ábrázolásairól a 20. század eleje óta találunk említéseket, gyüjtéseket. Az ostromról beszámoló 16-17. századi hazai és külföldi forrásokat ismertető újabb tanulmányokban és szöveggyüjteményekben az egri nők hősiességére vonatkozó eredeti szövegrészek is szerepelnek. ${ }^{1}$

Az ostrom után nem sokkal Egerbe érkező, tehát az eseményeket első kézből megismerő Tinódi Lantos Sebestyén (1510 k.-1556) az egri nők hősiességéről csupán néhány sorban emlékezett meg:

„Ott asszonynépek vitézködnek vala.

Lám sok köveket vártákra hordnak,

Nagy bátor szívvel ők hagyigálnak." ${ }^{2}$

A 17. század közepéig a magyarországi források - köztük külföldön nyomtatásban megjelenő munkák - az egri eseményeket elsősorban Tinódi alapján ismertették, ezért ezekben az egri nőkről ennél több információt nemigen találunk. ${ }^{3}$ Alapvetően ezt az adatot közölte Istvánffy Miklós (1538-1615) is 1622-ben Kölnben megjelent történeti munkájában, de az egyik súlyos ostrom visszaverésében már fontos szerepet tulajdonít a nőknek: Dobó István (1502 k.-1572) az „....asszonyállatoknak is, hogy az oda alámenő ellenségnek nyakokban köveket hányjanak s olvasztott szurkot vagy forró vizet öntsenek, keményképpen kényszeríti, akik engednek $s$ tehetségek szerint az parancsolatot véghezviszik, s mindenütt a kerítés oltalmazásában nagy sokat használ, úgy annyira, hogy az ellenség a viadalt alábbhadni és sokan elesvén bennek lassan-lassan hátramenni kénszeríttetnek." 4 Az asszonyok ugyanakkor olyan tevékenységeket végeztek - mintegy a fegyverrel harcoló férfiak keze alá dolgozva -, amelyek a kődobálás kivételével a női feladatokhoz álltak közelebb: forró víz, forró szurok, Gárdonyi Géza (1863-1922) Egri csillagokjában majd egy kondér forró, csípős gulyásleves öntése az ellenségre. Ennek hangsúlyozásával találkozunk Martonffy Károly (?-1869) 1868-ban megjelent, Székely Bertalan (1835-1910) Egri nők címü festményéhez (1. kép) kapcsolódó írásában is. A szerző történeti források alapján igazolja, hogy a várban nem voltak nemes vagy főrangú nők, csak sütőasszonyok és a közkatonák feleségei, akik a korabeli beszámolók szerint „...férfihoz illő bátorsággal köveket hajigáltak az ostromlókra". Az ostromban részt vevő nők testi ereje - vélte Martonffy - megfelelő volt a nagy kövek dobálásához, s „foglalatosságok kifolyása volt, hogy forró vízzel önték le a föligyekvő ellenséget..."

Az egri nők hősiességéről a hazaiaknál részletesebb beszámolót találunk külföldi történetírók munkáiban. Mai ismereteink szerint először Ascanio Centorio degli Hortensi itáliai történetíró 1566-ban Velencében kiadott munkájában olvashatunk vitézségükről: a legsúlyosabb támadásnál „egybegyült a város minden férfia és asszonya, akik a férfiaknál nem kisebb elkeseredéssel fegyverekkel, kövekkel, forró vízzel és más eszközökkel megannyi nőstényoroszlánként harcoltak, és az ellenség soraiban olyan félelmetes öldöklést vittek végbe, hogy az rettentó és sajnálatra méltó látványt nyújtott. Ugyanis e támadások során oly jeles esetek történtek, melyek méltók arra, hogy minden könyvben megemlékezzenek róluk. Ezek közül az első az volt, hogy egy anya lányával és vejével együtt a falakon kívül harcolt, megölték a férfit felesége közelében, erre az anya mondta neki, hogy menjen eltemetni, mire a lány azt válaszolta, hogy most nincs idő a temetésre és gyászszertartásra, hanem kegyetlen 


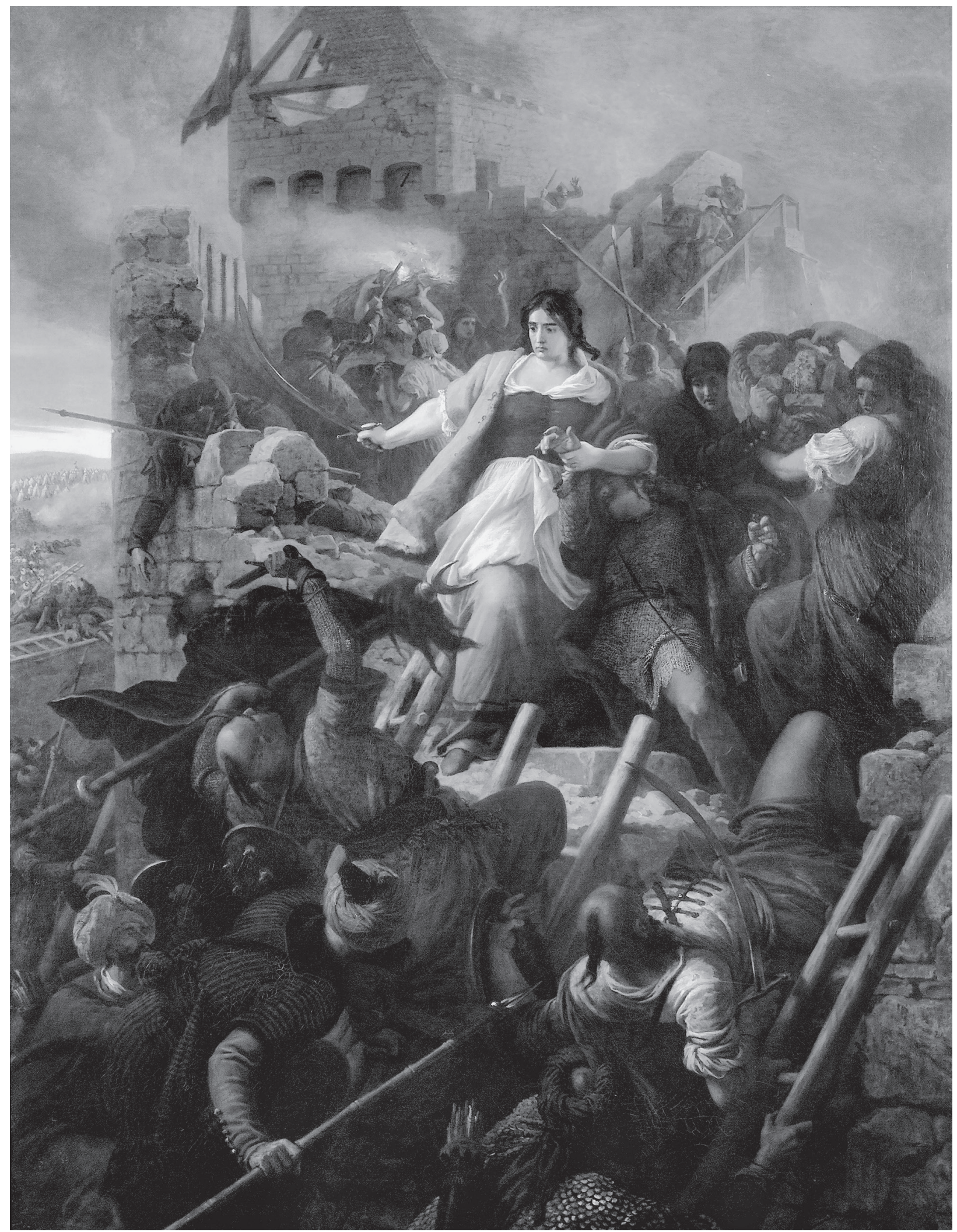

1. Székely Bertalan: Egri nók.

Olaj, vászon, 1867, Magyar Nemzeti Galéria 
bosszút kell állni, és magához vette kardját és pajzsát, a halott férj helyére állt, és hihetetlen dolgokat vitt végbe, és nem hagyta el addig azt a helyet, míg három török megölésével meg nem bosszulta férje halálát. Ezután férjét karjaiban a templomba vitte, ahol illendő tisztes temetést adott számára. Máshol pedig hasonlóképpen az történt, hogy egy asszony nagy követ cipelt a fején, hogy a várfalról a törökökre hajítsa, amikor egy lövedék leszakította a fejét és megölte, a vérrel összefröcskölt kő pedig leánya közelébe esett. Ô anélkül, hogy anyja halálának siratásával időt vesztegetett volna, felvette a követ, fejére helyezte, dühvel és haraggal így szólt: Anyám vére nem ontathatik ki megbosszulatlanul, és leánya nem élhet tovább anélkül, hogy másokon ne boszszulná meg halálát. Harci dühvel oda rohant, ahol a törökök a leghevesebben ostromoltak, és e nagy követ a lehető legnagyobb ellenséges tömegre dobta, két törököt megölt, kardjával pedig sok másikat megsebesített, valódi amazonként viselkedett, vagy valóságos spártai asszonyként. Ekkor mindenfelé szaladva biztatott mindenkit, hogy harcoljanak jól, emlékeztetvén őket eskűjükre és a rájuk váró dicsőségre Isten és az emberek előtt. Ezáltal elérte, hogy az ellenséget szégyenletesen visszaverték és a sáncok elé kijőve visszaszorították a többieket és a tüzérségi állások elhagyására kényszerítették őket." ${ }^{6}$

Centorio leírásában az egri nők már nem a parancsnok által munkára kényszerített főzőasszonyok, hanem önállóan cselekvő, a férfiakhoz hasonlóan fegyverrel harcoló - s mint a leírás folytatásából kiderül -, a harc véres brutalitásától sem visszariadó, félelem nélküli hősnők: „A létező legnagyobb ágyúkból kettőt azon a napon betömtek, és oly nagy volt minden bent lévő lelke, főként pedig az asszonyoké, akik férjeikkel, atyáikkal, fiaikkal és testvéreikkel együtt harcoltak oly bátran, hogy nem futamodtak meg még oly nagy veszélyektől sem. Egyik nap a törökök Egert ostromolták, az asszonyok pedig szokásuk szerint a halottak fegyvereit kezükben tartva álltak a várfalnál. Ekkor egy lövedék hármat vagy négyet megölt azok közül, akik a legelőrébb álltak, leginkább készen arra, hogy az ellenségre köveket és gerendákat hajítsanak. Megölt társaik vére és húsdarabjai a többi közel álló asszony arcába csapódtak, akik felindultságukban a fájdalom és félelem legkisebb jele nélkül, még dühödtebben tértek vissza a harcba bosszút állni megölt társaikon. A halott asszonyok vérével beszennyezett köveket felkapván még az eddiginél is elszántabban rohantak a csatába hallatlan dolgokat véghez vive. Ezekből a cselekedetekből ismerszik meg a hazaszeretet nagysága és ereje, mivel bátorságot ad még az oly gyönge asszonynak is ahhoz, hogy megvédjék. És valóban mindenki számára megmutatja, hogy nincs a világon drágább és értékesebb dolog, mint a haza, melynek üdvéért kötelesek vagyunk életünket és becsületünket egyszerre feltenni." ${ }^{7}$

A szakirodalom - Szekfü Gyula (1883-1955) írá$\mathrm{sa}^{8}$ alapján - úgy véli, hogy a nőkről szóló leírást Centorio azért találta ki, hogy beszámolóját érdekessé téve, „füszerezve” elégítse ki a török hódítás eseményei iránt érdeklődő nyugat-európai olvasók híréhségét. ${ }^{9}$ A két történet eredetére vonatkozóan nem találtam adatot, ${ }^{10}$ úgy vélem azonban, hogy a szövegrész vizsgálatakor nem hagyhatjuk figyelmen kívül azokat a korábbi nyugat-európai irodalmi törekvéseket, melyek a nők társadalmi szerepének, feladatainak, pozitív és negatív tulajdonságainak a bemutatására irányultak.

Giovanni Boccacciónak (1313-1375) az 13601370-es években keletkezett, De mulieribus claris (De claris mulieribus) címü, 106 tételt tartalmazó latin nyelvű női életrajzgyűjteményének hatása kimutatható a nőkkel foglalkozó későbbi munkákban, köztük Christine de Pisan (1365 k.-1429 k.) írónő Le Livre de la Cité des Dames (1405) címü könyvében. Boccaccio könyvének népszerúségét jelzi, hogy több mint 100 kéziratos másolat készült róla, s hogy a 15. században számos nyelvre lefordították. Az 1470-es évektől egyes részletei nyomtatásban is megjelentek, s Giuseppe Betussi (1512 k.-1573 k.) 1547-ben Velencében a szerző életrajzával kiegészítve kiadta Boccaccio munkájának olasz fordítását is. ${ }^{11}$

A női karakterjegyek meghatározásának részeként a 14-15. században kialakult az erős, harcos nők kánona is. A kilenc hős (Neuf Preux) analógiájára az irodalomban és a képzőművészetben létrejött a kilenc hősnő (Neuf Preuses) alkalmanként változó listája, melyre az első időkben elsősorban ókori személyek - a thébai mondakör hősnői mellett például amazonkirálynők (Sinope, Lampeto, Penthesilea) vagy a Cyrust (Kürosz) legyőző Tomyris szkíta királynő - kerültek fel. Hans Burgkmair (1473-1531) fametszetsorozatában három ókori, három ótestamentumi (Judit, Eszter, Jahel) és három keresztény „hősnőről" - köztük Magyarországi Szent Erzsébetről - készült ábrázolás. ${ }^{12}$

Az ebben a kulturális közegben otthonos Centorio tehát magától értetődően közölhette az egri ostromról szóló beszámolójában a női hősiesség kitalált vagy idegen forrásból átvett heroikus példáit. Leírása szemléletesen tükrözi azokat a karaktervonásokat, melyeket a korabeli (patriarchális) társadalom a férfiaknak és a nőknek tulajdonított, illetve azt, hogyan alakítja át a végletekig kiélezett helyzet, vagyis a pogány törökökkel a várért - tágabb értelemben a hazáért és a hitért - vívott élethalálharc ezeket a karakterjegyeket. A konszenzuális sztereotípiák szerint anatómiai, biológiai és pszichikai 
sajátosságaik miatt gyönge, támogatásra szoruló, érzelmeiknek kiszolgáltatott asszonyok az ostrom hevében férfiasnak tartott tulajdonságokat, kompetenciákat - határozottság, erő, győzelemre törekvés, kegyetlenség, illetve a gyász, a fájdalom, a félelem, a sajnálat leküzdésének, háttérbe szorításának képessége - mutattak. A szélsőséges szituációban a harcoló asszonyok dicsőségére vált, hogy a nőkkel szemben elvárt viselkedési mintákkal - megértés, érzékenység, alkalmazkodás, alázat, megbocsátás ellentétesen cselekedtek: kíméletlenül, kegyetlenül megbosszulták szeretteik halálát. Ahogy a (férfi) történetírónál az is helyeslésre talált, hogy a vitéz asszonyok a hagyományosan a nők számára fenntartott magánszférából átléptek a férfiak uralta közszféra fontos területére, a "theatrum belli" világába, azaz a hadszíntérre. ${ }^{13}$

Centorio a vitéz egri nők tetteinek bemutatásakor analógiaként említette, tehát vélhetően jól ismerte az ókori amazonok legendáját és a városukat védő spártai asszonyok történetét. Éppúgy, mint németországi kortársa, Melchior Junius (1545-1604) wittenbergi humanista, aki Cicero-kiadásában a spártai nők Pausanias által is leírt hősiességéhez hasonlította az 1552. évi egri ostromban harcoló aszszonyok bátorságát. ${ }^{14}$

Az egri nők hőstetteinek a teljes ostrombeszámoló felét kitevő bemutatása által, illetve leírása utolsó mondatával (hősiességük „mindenki számára megmutatja" a hazaszeretet erejét) Centorio olyan jelentékeny hangsúlyt adott, mely hamar felkínálta - mint látni fogjuk, évszázadokra - az exemplummá válás lehetőségét. Boccaccio említett női életrajzgyüjteményének 1596-os olasz kiadását egy itáliai humanista tudós, Francesco Serdonati (1540-1602) női biográfiái egészítették ki, melynek Donne Vngare címü fejezetében a két egri nő hőstettéről is olvashatunk. ${ }^{15}$

A vitéz egri nőkről szóló történetek elterjedéséhez hozzájárult, hogy szerepeltek az augsburgi Hieronymus Ortelius (Oertl) (1524-1614) térképekkel, metszetekkel illusztrált népszerü kiadványában. ${ }^{16}$ A két egri amazon hőstettéről több külföldi történeti munkában is olvashatunk, ${ }^{17} \mathrm{~s}$ a törökkel szemben a kereszténységet oltalmazó magyarok hősiességéről kialakult toposz (propugnaculum et antemurale christianitatis) illusztrációjaként megjelent a retorikai irodalomban is. ${ }^{18}$ A férfiakéhoz hasonlította az egri nők hősiességét a körmöcbányai Johann von Hellenbach a wittenbergi akadémián 1656-ban Magyarországról tartott, Oratio pro Hungarica címü szónoklatában: „,...] Most a magyar nők következnek, ők nem kevésbé, mint a férfiak, a hősök sorába sorolhatók. Amikor ugyanis 1552-ben Mahomet basa körülvette és megostromolta Egert, a nők akkora bátorságot tanúsítottak az ellenség

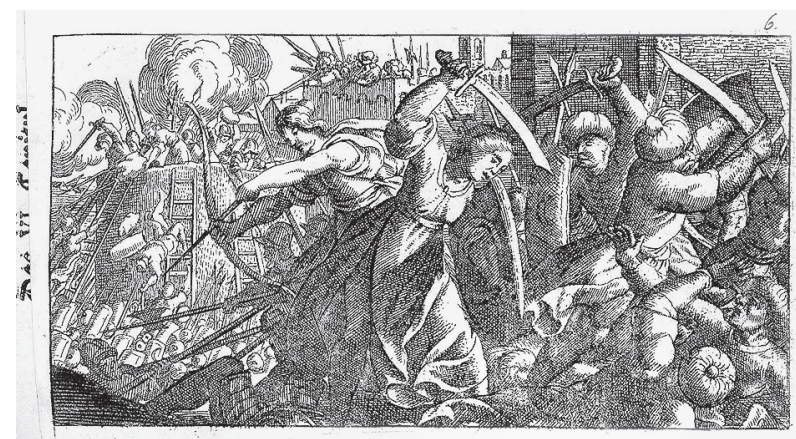

2. Könyvillusztráció. Hungarisch-Türkische Chronick ... Nürnberg, 1685. 128-129.

visszaverésében kövekkel, forró vízzel, csepúlánggal, hogy úgy vélhetnéd, inkább oroszlánok és medvék vitték végbe ezt, mint asszonyok” - majd ismerteti a két egri nő hőstettét. „Ennek a kitartásnak köszönhető, hogy az ostromzártól, amely 40 napig tartott, felszabadult a város. . [... $]^{\prime 19}$

A két amazon történetét közzétette egy először 1684-ben Nürnbergben kiadott krónika is, karddal, illetve nyíllal harcoló nőket ábrázoló rézmetszettel illusztrálva a hőstetteket ${ }^{20}$ (2. kép). A kiadvány címlapelőzékén egy nehezen olvasható jelzés - talán J. A. Baner (vagy Banet) sc. - található, feltehetően ez a metsző készítette a kötet többi, jelzetlen illusztrációját is, köztük a hős egri nőket ábrázoló 6. számút.

Az egri hősnők történetét ismertette két 17. századi erdélyi szász történetíró, Georg Krekwitz ${ }^{21}$ és Mathias Miles ${ }^{22}$ (1639-1686) is. Joseph Eder 1797ben újra kiadta Christian Schesaeus (1535 k.-1585) Ruinae Pannonicae (Pannónia romlása) címü müvének első négy könyvét, az egri ostromról szóló részben kiegészítésként szó szerint közölve JacquesAuguste de Thout említett könyvéből a két egri hősnőről szóló történeteket. ${ }^{23}$

A 18-19. század fordulóján a két egri nő hőstettéről több német, osztrák és magyar könyvben, folyóiratban találunk említést, melyek szerzői Francesco Serdonati 1596-ban megjelent életrajzgyüjteményét adják meg forrásként. Ezek a leírások - Serdonati női életrajzához hasonlóan - szinte mindig önálló történetek (anekdoták, emlékezetes cselekedetek, követendő példák). Az általam ismert első, Serdonati munkáját forrásként említő leírás 1773-ban Friedrich Heinrich Wilhelm Martini (1729-1780) berlini folyóiratában, Anekdoten címszó alatt jelent meg. ${ }^{24}$ A szöveg szinte szó szerinti átvételével ezután számos külföldi és hazai folyóiratban és könyvben találkozunk. ${ }^{25}$ A magyar fordítás 1816-ban jelent meg - a történet mellett átvéve a Serdonatira való hivatkozást is: „Midőn a' Törökök Eger Várát 1552 eszt. megszállották a' Városi Asszonyok az ő bátorságokkal és merészségekkel 
igen meg külömböztették magokat. Oda tódultak az ostromláskor, a' hol legnagyobb volt a' veszedelem, és forró vizet 's köveket hordottak férjeiknek, kik a' várt sántzokról védelmezték, mellyeket azok a' rohanó Törökök fejekre szórtanak.

A' Historia két bajnoki cselekedetet hagyott emlékezetben ezen ostromlás idejéből. Midőn legdühössebben vivták a' Törökök a' Várt, egy Aszszonynak, a' ki egy nagy követ vitt a' fejin, hogy azt a' bástyáról az Ostromlókra dobhassa, egy ágyú golyóbis fejét le szakasztá 's az a' mellett álló leányának lábaihoz halva roskadott le. A' leánya hazáért meg ölettetett Annyának szemlélésén nagyon megilletődött, és úgy gondolkodott, hogy az életre és Annyára érdemetlen volna, ha annak halálát meg nem bosszullaná. Tüstént fel kapta a' követ, mellyről még Annya vére tsöpögött dühössen a bástyára szaladtt véle, és azt a' hol az ellenség legtömöttebben volt, oda hajította. - Egy más vitéz tselekedet még okkal nevezetessebb ennél. Egy más ugyan azon Városbéli Asszony veje mellett állott, midőn az a' vár falain való véres tsatában el esett. Mihelyest holt testét földre rogyni látta, leányához fordulván, hidegen, és minden rémülés nélkül így szóllott: »Édes leányom férjednek csak meg fogod adni az utolsó tiszteletet? « Az ifjú Asszony nem kevésbé lévén bátor szívű mint az Annya minden könyhullatás nélkül így felelt! »Anyám most sem a' sírásra, sem a' temetésre idő nintsen, tsupán csak a' veszedelemről kell gondolkodnunk, 's drágán ki kell vásárlani férjem halálát az ellenségen.« Ezen szókkal meg ragadá elesett férjének kardját, reájok rohant az Ostromlókra és nagy bátorsággal hartzolt. Nem is távozott addig el a' nyilástól, mellyen az ellenség vívott, míg hármat közülök erős tsapásai alatt, le rogyni nem látott. Végre a' hadakozásba ki fáradván hátra vonult, hogy férjét el temethesse.

Francesco Serdonato és több magyar történet írók is azt jegyzették meg hogy sokan a' Városbéli Asszonyok közül az egész ostrom alatt minden meg szünés nélkül bátran és állhatatosan hartzoltak. Azért is egy vezér így szóllott katonáihoz, midőn őket bátorságokért megditsérni, és új vitézségre gerjeszteni akarta. „Vitézek nem szükség biztatni benneteket, hogy jól viseljétek magatokat, holott még az Asszonyok is, nemek gyengeségére való tekintet nélkül olly bátrak, hogy az ellenséget vissza vernék, és valóban nem kevés részek volt az Asszonyoknak a' győzedelemben.. ${ }^{26}$ Centorio 16. századi leírásából nemcsak az a vélemény él itt tovább, hogy szélsőséges helyzetben az asszonyok is képesek a cselekvést bénító érzelmek visszaszorítására, hanem az is, hogy a nők „,nemek gyengeségére való tekintet nélkül" a férfiakat megszégyenítő vakmerőséggel és harciassággal tudnak küzdeni.
A két egri nő története a 19. század eleji hazai és külföldi történeti munkákban is szerepelt. ${ }^{27} \mathrm{~A}$ motívum hazai elterjedését leginkább az 1840-es években megjelent magyar nyelvü történelemkönyvek és népszerü történeti munkák ${ }^{28}$ - közülük is elsősorban Horváth Mihály (1809-1878) könyvei - segítették elő, melyekben az egri nők példája hiteles eseményként szerepelt. A két történetet 1854-ben Kubinyi Ferenc (1796-1874) és Vahot Imre (1820-1879) is közzétette, ${ }^{29}$ kiemelve, hogy „....a nők is férfias bátorsággal lépnek elő a vár védelmére, $\mathrm{s}$ a benyomuló ellen sorait fegyverrel, kövek dobálásával s forró szurok és víz általi leöntéssel ügyekszenek hátráltatni..." ${ }^{30} \mathrm{Az}$ utolsó nagy ostromnál az „egri hősök nejei és leányai ... valamennyien részt vettek a vár védelmében s csak oly erőkifejtéssel, csak oly súlyos fegyverek- és elszánt vitézséggel harczoltak mint férfiaik, s velök együtt kivívták az örök hírü és dicsőségü »egri nevet« [...].

...Az egervári nők ezen példátlan vitézsége sokat tett férfiaik bátorítására; mert melyik férfi mert volna csüggedni és hátrálni ott, hol a gyöngébb nem az első sorban vív, s erején fölüli csodadolgokat visz végbe." ${ }^{31}$ Hangsúlyozták ugyanakkor, hogy a női tulajdonságok háttérbe szorítása csak a szükséghelyzet fennállásáig tartott: a győzelmet követő, egy hétig tartó áldomás idején az „„...egri hős nők...már ismét nők valának, a gazdasszonykodás gondjait oszták, s gyöngéd szerelmök- és családi érzelmeikkel boldogíták a vitézeket, úgy hogy az együtt harczolt ifjak és hajadonok közt hihetőleg a háborúskodás tovább-folytatása tekintetéből, néhány házassági frigy is köttetett." ${ }^{32}$

Remellay Gusztáv (1819-1866) író-újságírónak az egri ostrommal foglalkozó cikkében ${ }^{33}$ kiemelt szerepet kaptak a hazájukért harcoló asszonyok. Nemcsak a korábbi történeti források említéseit veszi át, hanem új - legalábbis az általam ismert leírásokban nem szereplő - jeleneteket költ hozzájuk. Az ostrom idején a sáncokat - írja - a helyi lakosokkal, köztük nőkkel és gyerekekkel erősítették meg, akik énekelve, hangyaszorgalommal dolgoztak. Mikor Dobó be akarta boríttatni a tetôket vizes bőrökkel, egy nőcsapat közeledett felé, élükön egy tisztes matrónával: „Vezér! tapasztalhattad előbb a védsánczok körüli munkánál, hogy Eger hölgyei felfogva, miként a hon, a közanya minden gyermeke szolgálatát, áldozatát sőt életét is joggal veheti igénybe, nem rettegnek a haláltól; láthattad, hogy bár közülünk nehányat megsebesítettek s meg is öltek a golyók, a többiek bátran, sőt énekelve folytatták a veszélyes munkát.

Minden férfi karja szükséges a vár védelmére, s így kötelességünk iparkodni, hogy minél kevesebb hős legyen kénytelen mással foglalkozni, mint a mi hivatása, a kard s lőfegyverek halált szóró ke- 
zelése; küld a falakra, küld a kapukhoz hőseidet, e munkát bízd reánk, s hidd, hogy habár golyózápor hull is fejeinkre a pataknál, oly nyugodtan, mintha a madarak dala mellett fehérítnénk vásznat, fogjuk a vízbe mártogatni, s oda, hol szükség lesz, elvinni a bőröket s pokróczokat.

»Igen, igen! bízd ránk e munkát!« kiálta valamennyi nő, s a legközelebbi perczben mindnyájan a patakhoz rohantak." ${ }^{34}$ Remellay narratívájában tehát a tipikusan férfi, illetve női feladatok elkülönítésekor a 19. századi társadalmi elvárásokkal is találkozunk: a nők a házimunkához (ruhaáztatás) hasonlító tevékenységgel segítik a hős férfiak harcát. A hazaszeretet természetesen - szintén egybecsengően a 19. századi szemlélettel - őket is éppúgy fúti, mint a férfiakat, s ezért vállalják a halált is. „Nemde szép kép ez olvasóim? amott küzdő férfiak, itt szép hölgyek... kiket mindnyájokat ugyanegy szent érzemény lelkesít, a magasztos honszeretet, $\mathrm{s}$ ugyanegy vágy buzdít a munkára - a vágy, minél több szolgálatot tehetni az imádott hazának..." ${ }^{35}$

Remellay ugyanakkor a történeti forrásokból átveszi - s kiszínezi - azokat a leírásokat is, amelyek szerint a nők a férfiakkal egyenlő bátorsággal harcoló, alkalmanként a csata kimenetelét is eldöntő amazonok voltak, akiknek testi és lelki erejét megsokszorozta s a férfiakéhoz hasonlóvá tette a végveszély közelsége és a kíméletlen bosszúvágy: „....néhány percz még, s el lett volna veszve a vár, de a legnagyobb veszélyben, midőn már mindenfelé a falakra hágtak a törökök, egy nő, ki látta, hogy férje elveszett, annak vérző testéhez rohanván, felkapta kardját, s mint kisdedeit vesztett párducz, rohant a pogányok felé.

Példájára azonnal hasonló cselekvésre lelkesült több nő s nehány percz mulva a mely hölgy csak kardra, puskára vagy lándzsára tehetett szert, a férfiakkal vetélkedve küzdött a pogányokkal, azok pedig, kiknek nem jutott fegyver, egy kedveséért bosszút állni akaró ara példáját követve, köveket hengergettek a falak szélire, s lezuhantatták azokat az ostromló janicsárokra.

A vágy minél több kárt tehetni a törökökben, $\mathrm{s}$ a bosszúszomj, mert többen elvesztették már férjeiket, kedveseiket, s testvéreiket - óriási erővel ruházta fel némely nő karjait, - így hogy többeket ne említsek, Pozsgay János neje, midőn látta, hogy két golyó által találva rogyott össze férje, bőszen rohant egy nagy kődarabnak, s a roppant tömeget, melyet máskor meg se tudott volna mozdítani, most a fal széléig hengerítve, zuhantatta alá az ostromló pogányokra, s azután felkapván férje kardját, mint a hagyomány mondja, hat törököt mészárlott le addig, míg minden ponton visszaveretett a vívó sereg." ${ }^{36}$

Remellay ismertette a Centorio munkája óta hagyományozódó két jelenetet is: „E véres napról több nagyszerü esemény emlékét örökítette meg a hagyomány, - ím lássunk néhányat a sokak közül. Egy nő nehéz követ vevén fejére, sietett a bástya szélihez, s midőn már már oda ért, földre teríttetett egy ágyúgolyó által, mire leánya, ki nyomban követte, hirtelen fejére vette a követ e szavakkal: »Így fejezi ki fájdalmát az anyát vesztett egri nő dobta le az ostromlókra, s csak miután látta, hogy két törököt zúzott össze a nagy kő, tért vissza anyja holttestéhez, hogy forró könnyeivel áztassa. Más ponton egy férj, nő, s ennek anyja vívtak egymás mellett, a bajnok elesett, mit látva így szólt az anyós: »Leányom, vitesd haza férjed vérző holttestét, s a bosszút bízd rám! « »Nem, nem anyám! én nem távozom oldalad mellől - felelt az özvegy - előbb megbosszúlom férjemet, s azután borulok könnyezve holttestére." Ezt mondva kezébe ragadta férje kardját, s elszántan előre rohanva, addig küzdött, míg négy törököt mészárolt le, mert azt tette fel, hogy férje koporsója alá a négy faláb helyett ugyanannyi török fejet fog tétetni.

Ilyen példák után csodákat kellett véghez vinni a férfiaknak..." 37

Remellaynak - aki szerint történelmünkben „,... ha csak felületes számítást teszünk is, több mint ezer hölgy szerzett hazájára nézve annyi érdemet, hogy megörökítette nevét..."38 - a magyar nők históriai szerepe iránti érdeklődését jelzi néhány évvel később megjelent kétkötetes kiadványa is. ${ }^{39}$

A két vitéz nő motívumával találkozunk Pauler Gyulának a Vasárnapi Ujságban közölt, az 1552. évi egri ostrommal foglalkozó sorozatában is: az utolsó nagy ostrom alatt az „,egri nők a férfiakkal vetekedtek. »Megboszullak!« mondá egyik haldokló férjének, és csapásai alatt három török hullott el. Egy másik megölt anyja kezéből kiragadá a követ, és a tar fejekre lódítá." 40

Az egri nők hősiessége a 18-19. századi hazai szépirodalomban is kedvelt téma volt. 1700-ban Telekesi István (1633-1715) egri püspök felhívására egy, az 1552. évi ostromról készült színdarabot adtak elő a helyi jezsuita kollégium diákjai a várfal tövében lévő szabadtéri színpadon. Bár a ránk maradt színlap szerint női szereplők nem voltak a darabban, a színjáték tartalmát ismertető kivonatban (Argumentum) szerepel a két vitéz nő története, s megemlítik a forrást, Centorio könyvét is. ${ }^{41} 1729$-ben a pozsonyi jezsuita kollégiumban mutatták be a „Keresztény Hercules Avagy Achomet Vezéren dücsőséges diadalmát vévő Dobo István Eger-Várának Fő Kapitánya" címü darabot, melyben a következő jelenet is szerepelt: „,...Tizedik ki-menetel. 


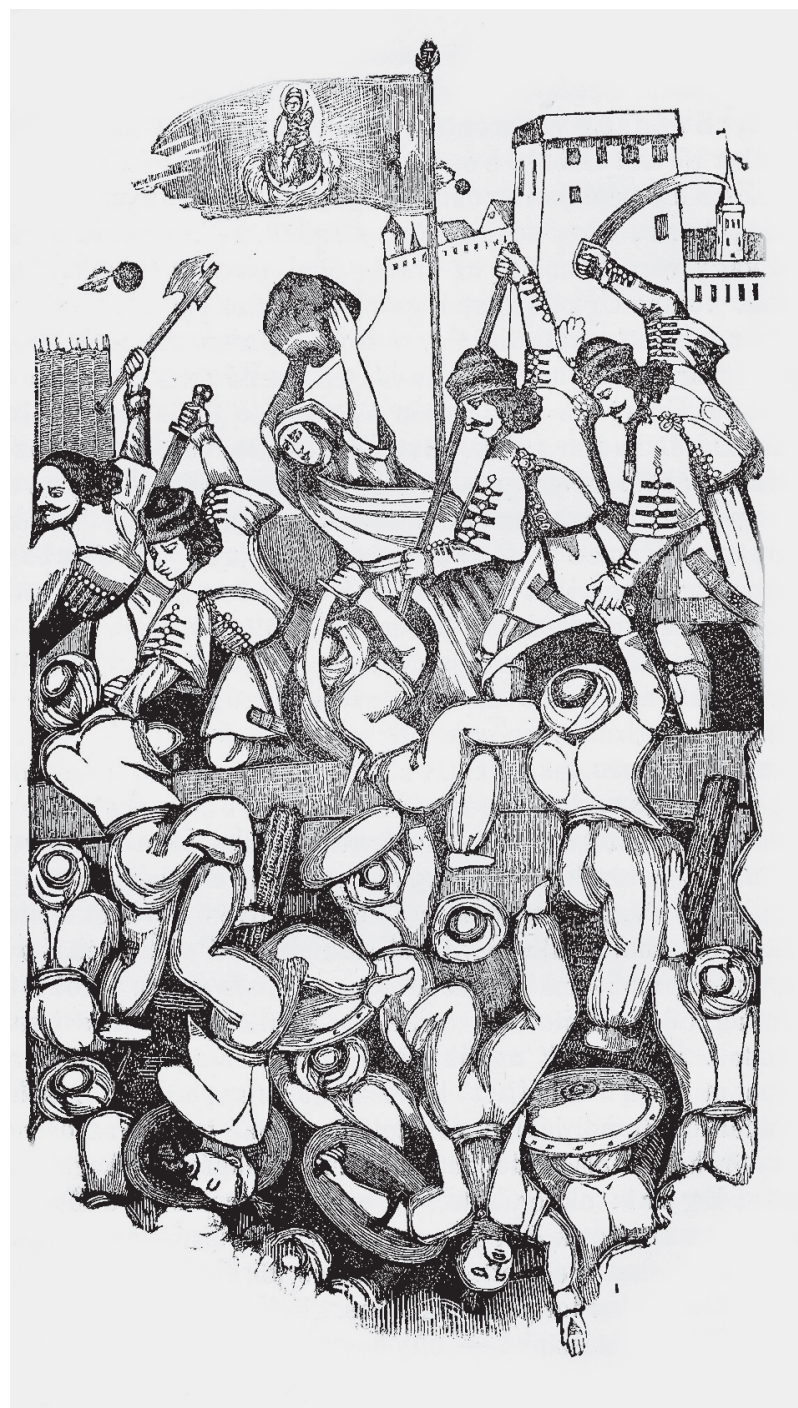

3. Könyvillusztráció. Dr. Lányi Károly: Magyar nemzet történetei képekkel a nép számára. Pozsony 1846, 172.

Dobó, Meczkeit ellenségbűl, a' mint vélé jó akarújává kivánván tenni, erősségéért meg dicséri. Amaz néki bátorítván első akar lenni az ütközetben, de Dobó attul tartván, hogy által szökik, a' setétségbe helyhezteti. Rosinda jeles-Aszszony Dobónak házas-társa, a' tisztek példájátul ösztönöztetvén, késérőivel, és fiacskájával edgyütt, magát az várnak oltalmazására ajánlya." ${ }^{42}$ Dobó felesége, Sulyok Sára a kor szokásához híven valójában nem volt Egerben az ostrom idején.

A halott férje kardjával harcoló nő történetét dolgozta fel Eggy Egri Aszszony' Vitéz Tselekedete címü, 1786-ban megjelent költeményében Baróti Szabó Dávid (1739-1819), élvezettel merülve el a harc hevében női mivoltáról megfeledkező, bosszúálló feleség vérengzésének részleteiben. Az ókori amazonkirálynőhöz, a bátor Penthesileához hasonlított asszony „elméjéből kirekesztvén asszonyi létét... ...s nem gondolván maga vesztivel, önti

A sok vért; sokakat lenyakaz, kardjával halált szór.

Mint villog Simois vizinél a lányi seregben

Penteziléa: ki mer szóllítani bajra vitézlő

Férjfiakat, pusztít görögöt, s a közbe kerített

Trójától gyors fegyverivel szaladásra rohantat."

„....S újra

Vérengzéshez fog, valamint a mérges oroszlány,

Melly mikoronn, az ünő vérét ízlelni találta,

Más meg más prédára rohan: darabokra szakasztja

$\mathrm{S}$ a kóstolt vérben testét kedvére fereszti.

... [...]...

(Olly tehetôs a bánat, harag!) s illy szózatit adja:

Asszony vólt leverőd: van mit dicsekedjem; eredj már

Nemtelenebb más lelkeknél, mivel érdemes arra

Nem vóltál, hogy férjfi vitéz verjen ki világból." ${ }^{43}$

Szigligeti Ede (1814-1878) Az egri nók címú színmúve (1851), Tárkányi Béla (1821-1886) egri papköltő Egri Amazon című balladája (1857), ${ }^{44}$ Tóth Kálmán (1831-1881) Dobó Katica címú vígjátéka (1862) ${ }^{45}$ többnyire elszakadt a történeti forrásokban található eseményektől, bár egyes motívumok megjelennek bennük. Szigligeti müvében az egyik szereplő, Ágota az ostrom idején haldokló anyjától elragadott kővel sújtott agyon két törököt, ${ }^{46}$ Zalár József (1825-1914) pedig Dobó és az egri nők címü költeményében a férjét megbosszuló nő alakját eleveníti fel:

„...- És rohanják Egervárát Ahmet katonái;

De elibök állnak Dobó

Fiai s leányi.

Tigrisek másznak a falra

Törökök képében;

De oroszlányok fogadják

Magyarok nevében.

Ha elestél, kedves férjem,

Kezemben a kardod,

Megboszulom halálodat,

Dobó apám, hallod?" 47

Pájer Antal (1814-1881) papköltő, aki két verset is szentelt ${ }^{48}$ a vitéz egri nőknek, Az egri amazonok című költeményében - megénekelve a férjét megbosszuló asszony történetét - azt hangsúlyozza, hogy a nők szükség esetén éppúgy lehetnek a haza védőpajzsai, mint a férfiak:

„....Mi hát a' gyáva nő, ha férfi nincsen?

- Zugták a' rágalom csipős szaván -

Egy otthon üldögélő drága kincsem!

A' fényüzésnek puha pamlagán.

'S míg a' férjnek bősz csatáknak áldozatja, -

Ő honn, szerelmét egy pulyának adja... 
... Igy szálla szét a' gúny csipős fulánkja,

Hogy szinte a' magasba felhatott.

's az úr szent bosszut esküvén reája,

Lemennydörögte a' határzatot:

»A' gyönge nő, kit rágalomtok ére,

Védpajzsotok lesz, ezrek szégyenére...

...De ím, a' gyönge nők tüzelt erében

Mi rendkívüli hévnek lángja gyúlt?

Kard, dárda fénylett mindenik kezében,

's csodás merénynyel égve, rontva dúlt:

Ez itt önférje izmos gyilkolóját

Villámkardjával percz alatt szelé át...

...Midőn Egernek eltarolt vidékén

A' béke visszaszállt parányira,

Szegény hazánk a' jóslat bús igéjén

Egy kínos eszmélettel fölsira:

'A' gyenge nő, kit rágalomtok ére, -

Védpaizsotok lőn, ezrek szégyenére!...«" 49
A vitéz egri nők emlékét néhány, Székely Bertalan festményénél korábbi, 19. századi hazai ábrázolás is megörökítette. Egy 1846-ben kiadott népszerüsítő kiadvány illusztrációján harcoló férfiakat, a kompozíció középpontjában pedig az ellenségre követ dobó nőt látunk ${ }^{50}$ (3. kép). A könyvben nem találjuk a két vitéz nő Centoriótól származó történetét, itt tehát a kődobálás a Tinódi-féle hagyományt illusztrálhatta, vagyis hogy a nők köveket, forró vizet és szurkot zúdítottak a törökökre. 1851-ben Párizsban franciául, majd 1852-ben Stockholmban svéd nyelven jelent meg Boldényi János ${ }^{51}$ Magyarország történetét összefoglaló munkája, melynek egyik, François Auguste Trichon (1814-1898) által készített kőmetszetes illusztrációja egy hatalmas követ ledobó egri nőt ábrázol ${ }^{52}$ (4. kép). Bár ennek a kiadványnak a szövege is csupán általánosságban beszélt az egri nők hősiességéről és bátorságáról, tehát nem tartalmazta az anyja halálát megbosszuló lány történetét, elképzelhető, hogy a kép ezt a jelenetet elevenítette fel: a heroikus elszánást és dühöt tükröző tekintetü fiatal nő előtt egy asszony holtteste fekszik. Ugyanez az illusztráció - csak jelzés nél-

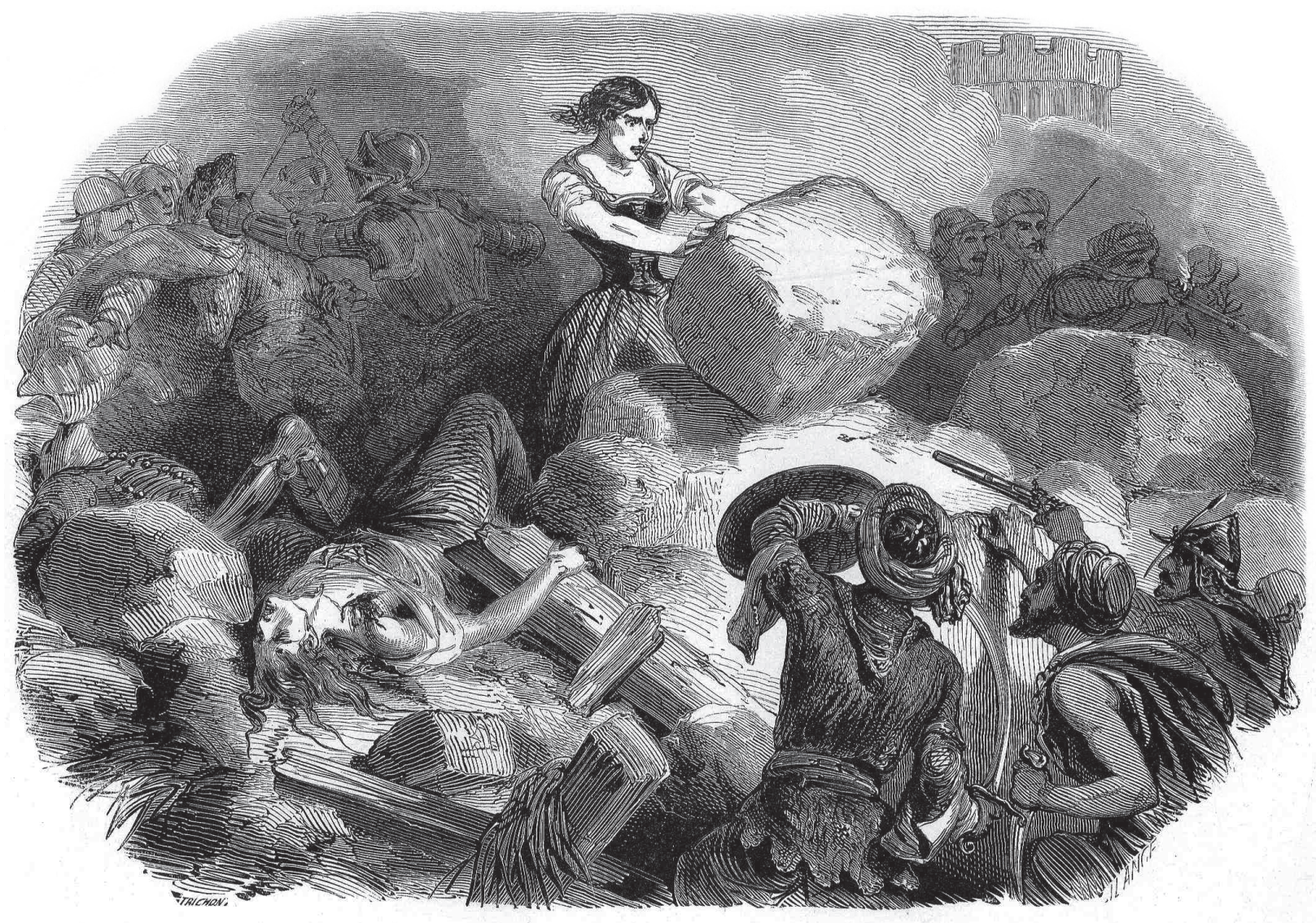

SIEGE D'AGRLA PAR LES OTTOMANS

4. Könyvillusztráció. La Hongrie Ancienne et Moderne.

Histoire, Arts, Littérature, Monuments par... M. J. Boldenyi. Paris 1851, 152-153. 


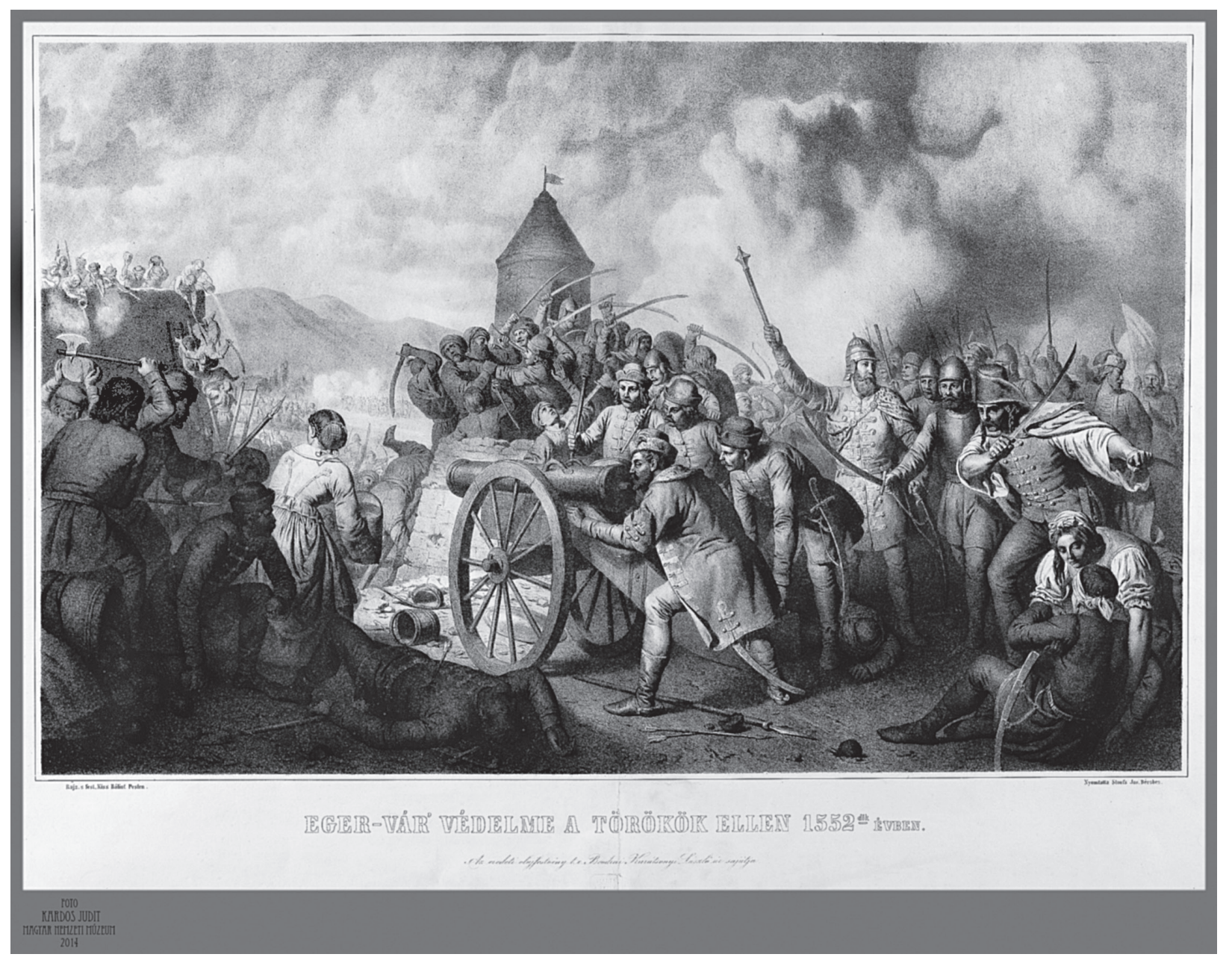

5. Kiss Bálint: Eger ostroma. Litográfia, 1858 körül

kül - jelent meg 1853-ban egy Londonban kiadott történeti munkában, mely szintén nem ismerteti a két történetet, ${ }^{53}$ illetve három hazai újságban. ${ }^{54}$ Közülük a Magyar Néplap - mint láttuk - hosszabb írást közölt Eger ostromáról, ezt illusztrálta a kép.

Kiss Bálint (1802-1868) 1858 körül készült, lappangó festményén, melynek litografált változatát a müvész 1859-ben a Nemzeti Múzeumnak ajándékozta $^{55}$ (5. kép), a bal felső sarokban a falakon álló, forró vizet és követ dobáló férfiakat és nőket látunk. Az előtér bal oldalán egy nő áll háttal a szemlélőnek, a kezében lévő edényből a törökökre öntve a forró vizet. A jobb oldali előtérben egy nő átölel vagy felemelni akar egy földön fekvő férfit, akinek kard van az oldalán. Ezen a képen tehát a nők fegyverrel nem harcolnak, csak forró vízzel és kővel, s a kép jobb oldalán látható asszony is inkább nőies munkát - a sebesült vitéz segítése - végez. A kompozíció középpontjában egy ágyút elsütő férfi és más harcosok, illetve Dobó István van, a nők ezen a képen csak mellékszereplők.
Vizkelety Béla (1825-1864) Eger várának hősi megvédése címú kompozíciójának litografált változata a Vahot Imre által szerkesztett Napkelet címü hetilap 1860. évi mülapja volt (6. kép). A Kubinyi Ferenc mellett Vahot közreműködésével készült, említett 1854. évi képes kiadványban mindkét vitéz nő története szerepelt, s mindkét jelenet feltünik a Vizkelety kompozíciója alapján Franz Kollarž (1829-1894) által készített kőrajzon is. A férjét, illetve az anyját megbosszuló két nő történetét Vahot - aki a festmény kompozíciójának tervezésében is részt vett ${ }^{56}$ - a kép 1860-ban megjelent, Eger várának hősi megvédése, 1552-ben. Magyarázatul Vizkeletinek hasonczímü remek történeti képéhez címü írásában is ismertette: „Többi közt egy nő, kinek férje a vár védelmében oldala mellett elesett, a hullát nem akará addig eltemetni, míg boszút nem állott a törökön. Kezébe ragadta tehát elhunyt férje fegyverét, ennek helyére állott, vívott, megsebesült, s addig nem szünt meg harczolni, míg a falra tolakodó ellen közül hármat meg nem ölt. - Ekkor aztán, mint ki engesz- 


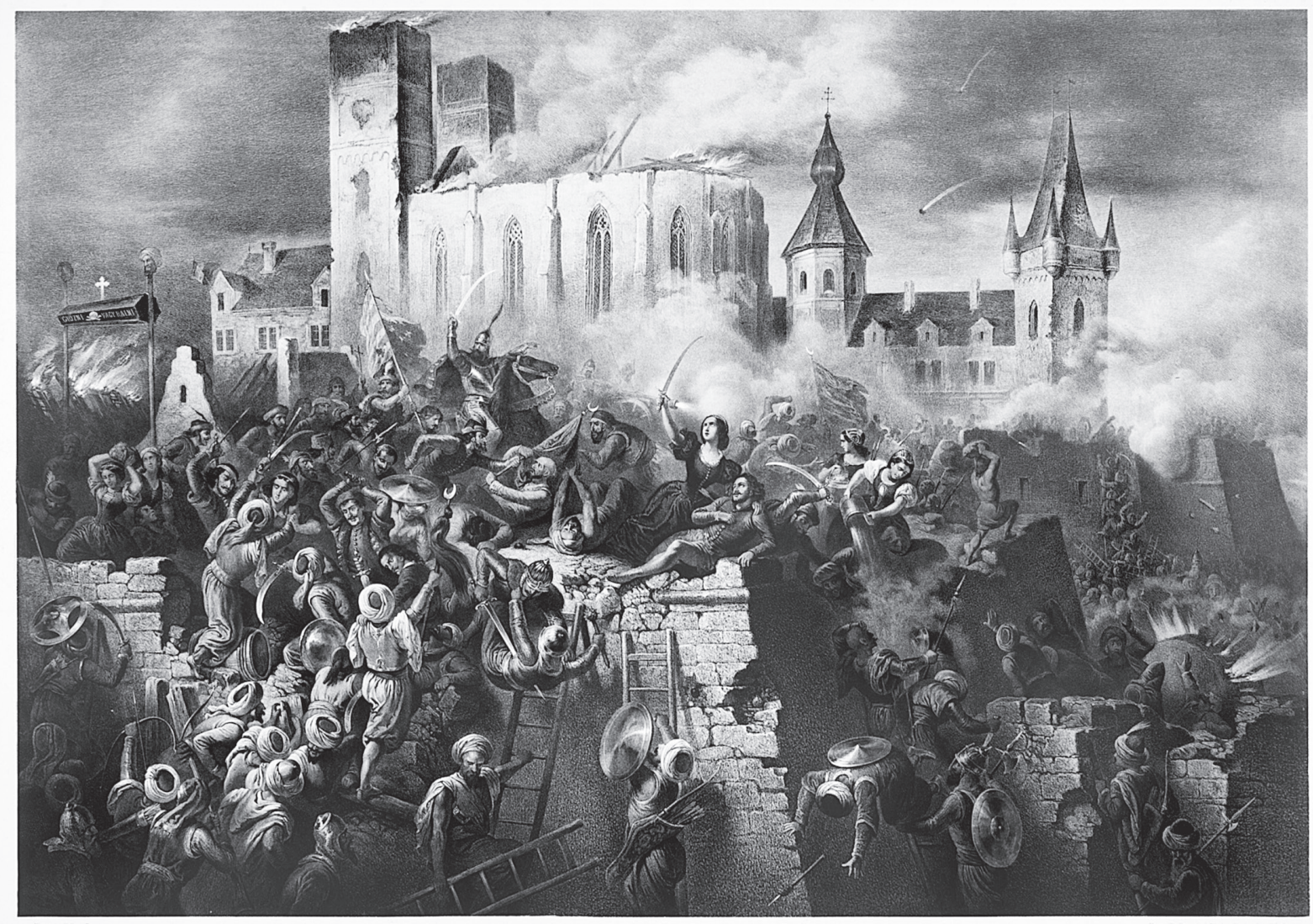

6. Vízkelety Béla - Franz Kollarž: Eger ostroma 1552-ben. Litográfia, 1860 körül

telő áldozatot hoza férje szellemének, nyugodtan takarítá el holt tetemeit.

Egy más nő az egerváriak közül, egy nagy követ czipelt a fején oly czélból, hogy azt az ellenségre dobja le. Ámde véletlenül egy lövés elszakasztja fejét. Meglátván ezt leánya, fájdalom- és boszuérzet fogja el, a véres követ felkapja, s oly erővel hajítja le a török közé, hogy kettőt közülük agyonüt, kettőt megsebesít. (Mindkét jelenet látható képünkön.) ${ }^{\prime \prime 57}$ Székely ismerte Vízkelety képét, hiszen egyik levelében a „mindent festeni akarás" elrettentő példájaként említette. ${ }^{58}$

A hazai kutatás azt feltételezi, hogy Székely Bertalan Egri nők címü festményéhez ${ }^{59}$ Horváth Mihály történelemkönyve jelentette az inspirációt megemlítve, hogy erre az összefüggésre már a korabeli kritika is felfigyelt. ${ }^{60}$ Nem zárhatjuk ki ezt a feltevést, a Székely által ábrázolt két motívum (az elesett férje kardjával harcoló nő, illetve a követ dobáló anya és lánya) azonban a 16. század óta olyan sok hazai és külföldi leírásban szerepelt, hogy Székely - aki históriai festményei témáinak kidolgozásakor gyakran nézett utána a vonatkozó történeti irodalomnak ${ }^{61}$ máshol is találkozhatott velük. A kép egy részlete ugyanakkor alátámasztani látszik, hogy Székely ismerte Horváth egyik kiadványát. A történetíró három könyvének leírásai között csekély eltéréseket találunk, ezek egyike az, hogy az 1844-ben megjelent mű szerint „egy asszony kosarában súlyos szikladarabot emelve sietne a fal párkányához, hogy azt a feltörekvő ellenségre hengerítse", majd halála után a mellette vívó leánya „bosszútól izmosult karokkal ragadja meg az anya vérétől párolgó kosarat és a követ olly erővel sújtja a feltörekvő törökökre, hogy kettő közölök agyon sújtva hullott le a hágcsóról." ${ }^{62}$ A másik két leírásban a nő a fején vitte a nagy követ. A korábbi történeti és irodalmi művekben - Centoriótól kezdve - a kosár motívuma nem bukkan fel, elképzelhető tehát, hogy Székely forrásául Horváth Mihály 1844-es könyvének szövege szolgált - igaz, Székely a kosárban nem egy nagy, hanem több kisebb követ festett meg.

Bár a szakirodalom hangsúlyozza, hogy "Székely motívumválasztását ... nem az említett tör- 


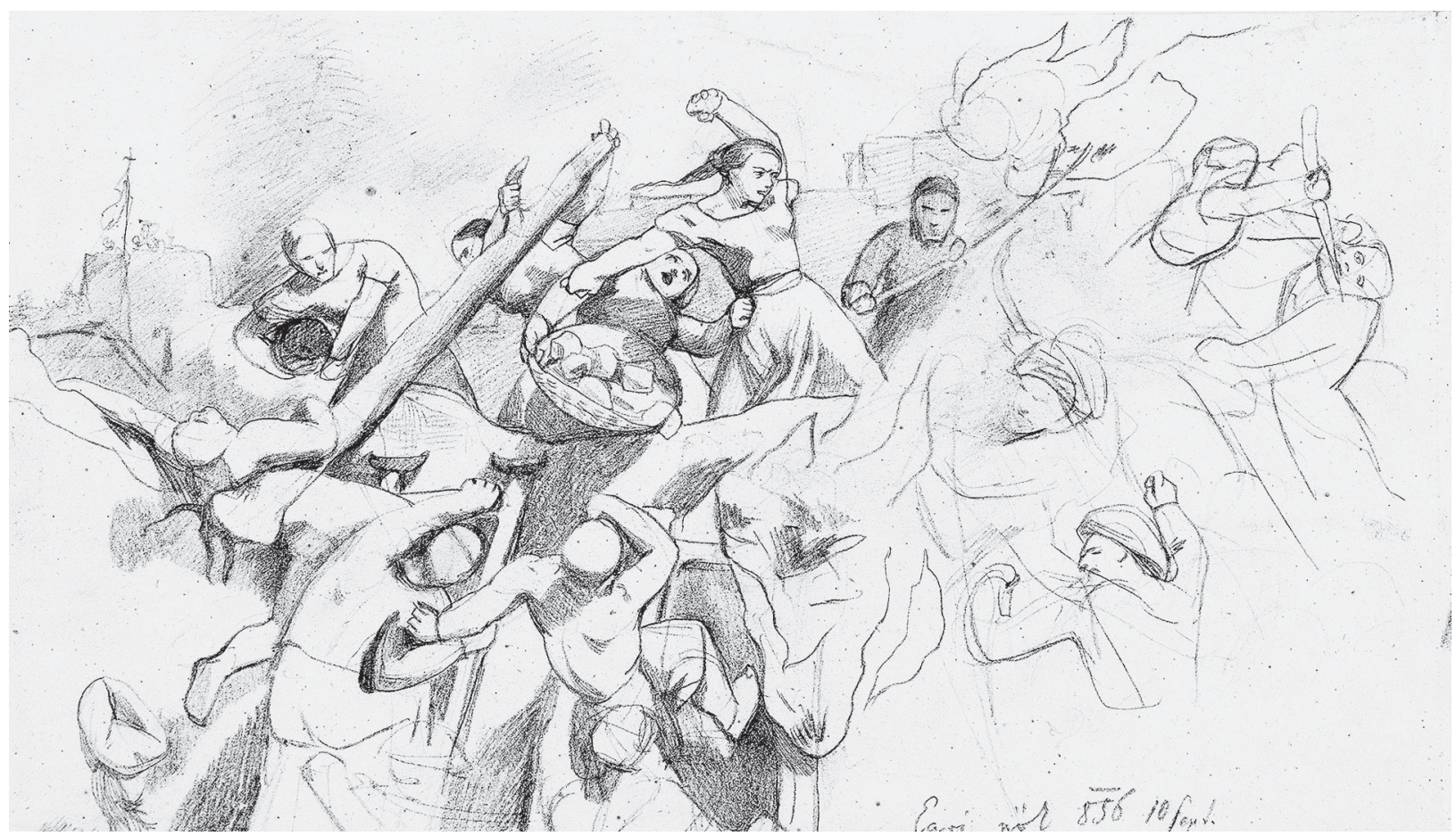

7. Székely Bertalan: Vázlat az Egri nókhöz, 1856. Magyar Nemzeti Galéria, Grafikai Osztály, ltsz. 1917-351

téneti munka befolyásolta, hanem a védelemben a hősiesség és a bátorság hangsúlyozása, amelynek kézenfekvő lehetősége lett volna a túlerő valamiféle érzékeltetése", ${ }^{63}$ úgy tünik, a két történet fontos szerepet játszott a kompozíció kialakulásában. Erre utal, hogy a képhez készült első ismert vázlatokon - ahogy erre Sinkó Katalin is rámutatott ${ }^{64}$ - még sokkal szorosabb volt a kapcsolat a történeti munkákban szereplő leírásokkal.

Székelynek a Magyar Nemzeti Galéria Grafikai Osztályán őrzött vázlatai között van egy 1856. szeptember 10-i keltezésű, Brassóban készített ceruzarajz, melynek középpontjában egy fiatal nő áll, aki „erôteljes, dühös mozdulattal”65 egy követ dob a törökre. Mellette egy idősebb nő látható, aki miközben öszeesik, egyik kezével a lány szoknyájába kapaszkodik, másikban egy kövekkel tele kosarat tart. Székely tehát - úgy túnik - először a halott anyját megbosszuló lány történetével kísérletezett $^{66}$ (7. kép). A következő évben készült, Erlauer Weiber 1857 feliratú lapon két nőt látunk, akik közül az egyik egy nagy követ készül ledobni, a másik kardot és pajzsot tart a kezében. A meglehetősen vázlatos rajzon a kardos-pajzsos nő előtt egy férfi, a követ dobó nô előtt pedig egy asszony teste látszik, a két történet motívumai tehát itt is felfedezhetôek $^{67}$ (8. kép). Egy 1859 decemberéből származó lapon egy fiatalabb nő átveszi egy idősebb nő fejéről a kosár követ ${ }^{68}$ (9. kép). Egyértelműen a történeti források hatását mutatja két későbbi vázlat: egy „1860 februar” feliratú ceruzarajz felső részén egy nagy követ ledobó nőt látunk, akinek a kezébe egy összeeső nő kapaszkodik, középen pedig egy karddal harcoló nőt. Közvetlenül ez előtt a jelenet előtt tussal hangsúlyozva egy másik nő áll, aki egy összeeső férfit ölel át ${ }^{69}$ (11. kép). Hogy Székely a halott férj fegyverével tovább küzdő nő történetét akarta ábrázolni, jelzi a kép bal oldalán található „nimmt dem marine schild und schwerts" szöveg. ${ }^{70}$

Ennél is egyértelmübben kimutatható a történeti források hatása egy 1860 januárjában keletkezett vázlaton, melyen fent egy kosárból köveket ledobó nőt, egy előtte összeeső asszonyt, illetve - a kép közepén - az egyik kezében kardot, a másikban halott

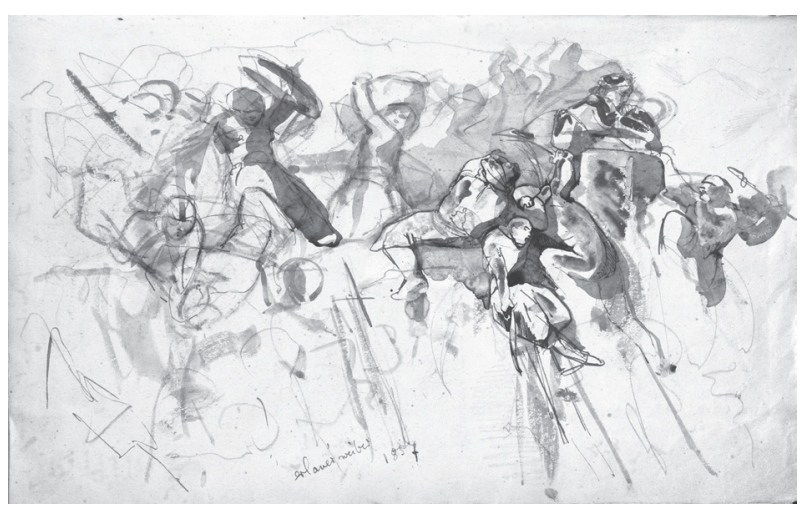

8. Székely Bertalan: Vázlat az Egri nókhöz, 1857. Magyar Nemzeti Galéria, Grafikai Osztály, ltsz. 1915-1760, 13v (14) 


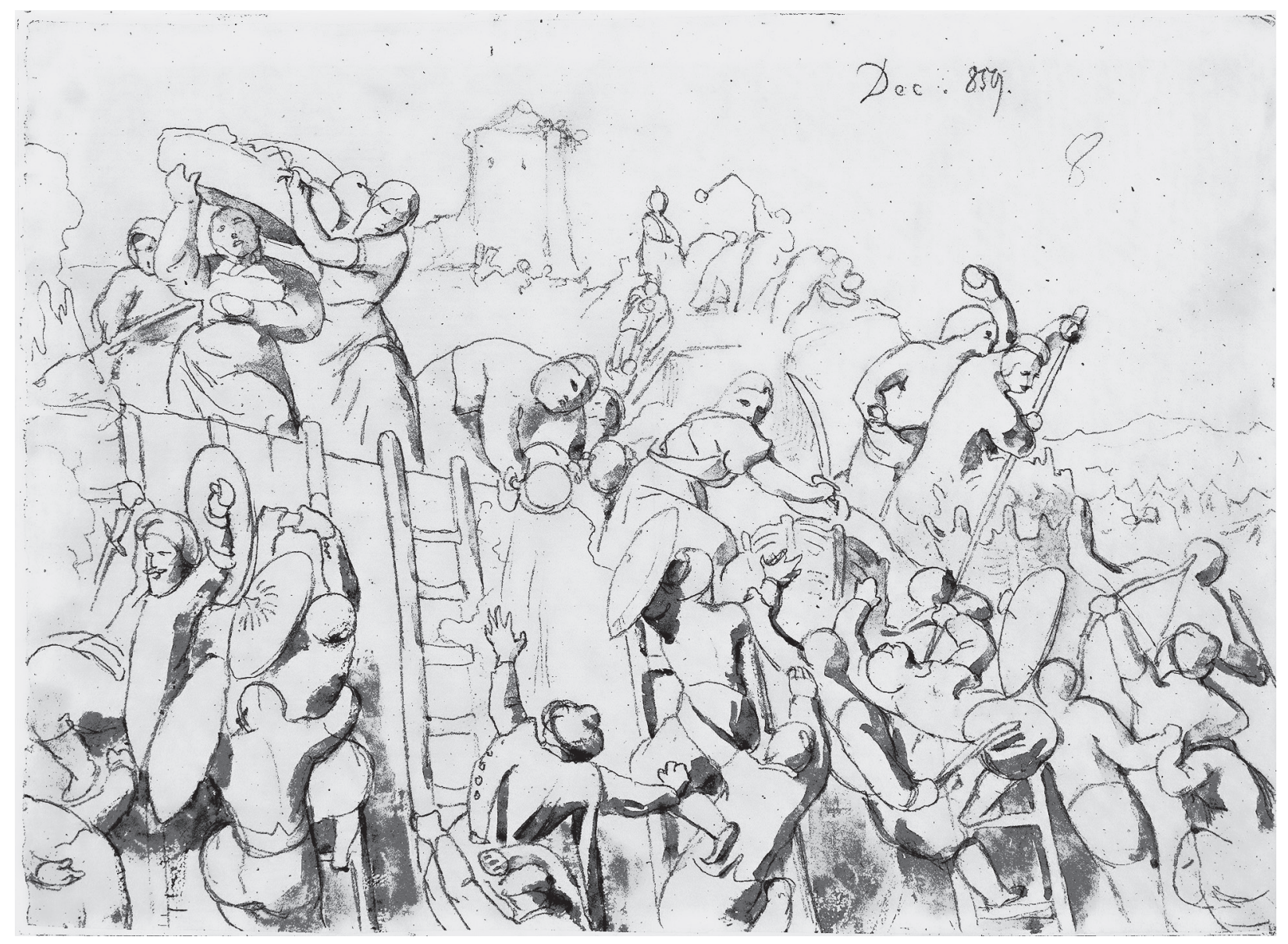

9. Székely Bertalan: Vázlat az Egri nókhöz, 1860. Magyar Nemzeti Galéria, Grafikai Osztály, ltsz. 1917-359

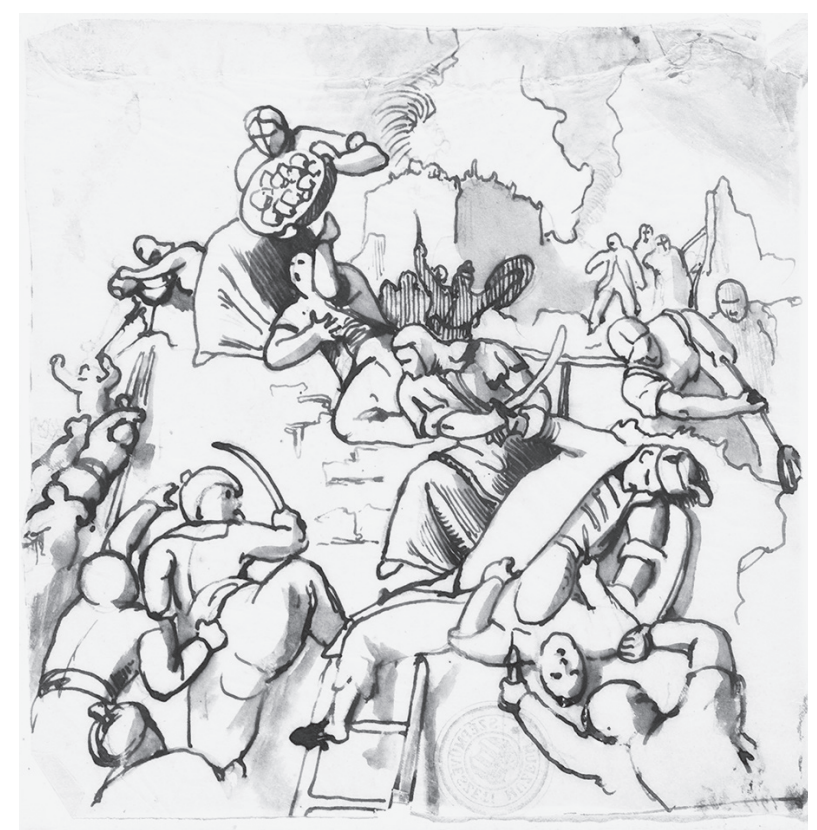

10. Székely Bertalan: Vázlat az Egri nókhöz, 1860. Magyar Nemzeti Galéria, Grafikai Osztály, ltsz. 1915-1760, 173. lap férje kezét fogó amazont látunk ${ }^{71}$ (10. kép). Két 1860 végén készült szépiarajz jeleneteit is a két történet inspirálta: az egyik kép felső részén a lány kezében a kosár követ látjuk, amint a törökre dobja, alatta egy hátulról ábrázolt fekete ruhás, kendős nő estében nyúl a kosárért ${ }^{72}$ (12. kép). Egy másik vázlatrajzon a fiatal nő szintén eldobja a köveket, a fekete ruhás idős nő pedig lehanyatlik vagy nyúl érte, de itt elölről ábrázolva ${ }^{73}$ (13. kép). Mindkét kompozíció középpontjában a halott férjétől a kardot elvevő nő látható, egyiken átöleli lehanyatló férjét, a másikon a kezét fogja. Ezeken a vázlatokon tehát már az olajfestmény fiatal nő - fekete ruhás idős nő párosa jelenik meg, de az idős nő még nem a fiatal mellett áll, hanem elesik vagy guggol. A vázlatokon szereplö, követ dobó leányt és a haldokló vagy halott anyát „,a végleges változaton ott látjuk...együtt, küszködve a kövekkel teli kosárral. A nagy mú főalakjai nem az anya és leánya csoportja, hanem az elbukó férje kezéből kardját kiragadó amazon lett." ${ }^{\prime 74}$

Egy 1861 novemberében keletkezett vázlat kompozíciója még jobban közelít a majdani festményéhez: a kép középpontjában a jobb kezében kardot 


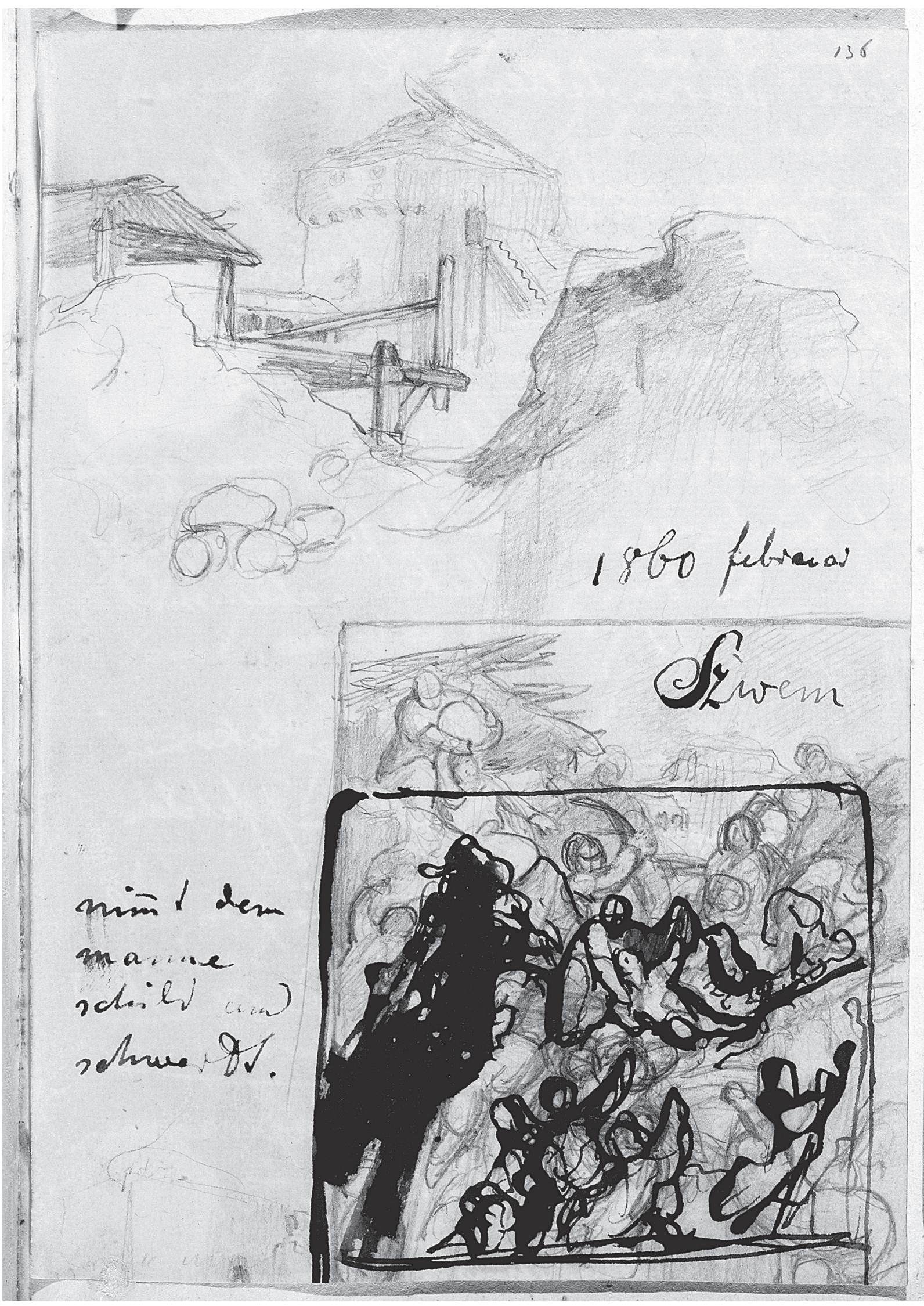

11. Székely Bertalan: Vázlat az Egri nókhöz, 1859. Magyar Nemzeti Galéria, Grafikai Osztály, ltsz. 1915-1760, 171. lap 


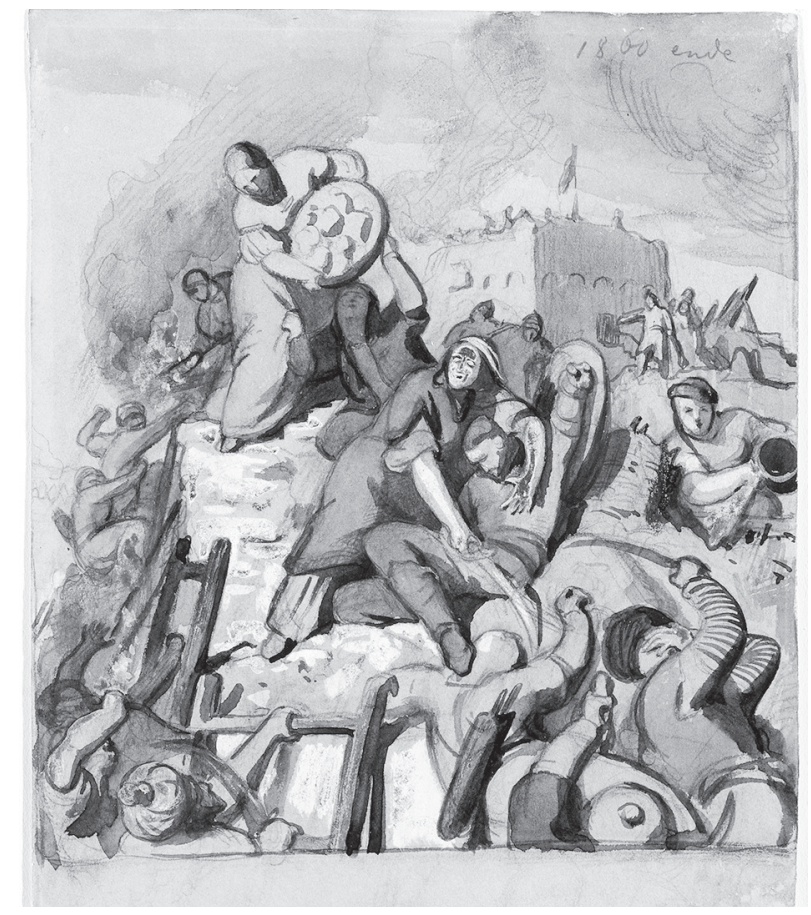

12. Székely Bertalan: Vázlat az Egri nókhöz, 1860. Magyar Nemzeti Galéria, Grafikai Osztály, ltsz. 1917-363

emelő, bal kezével halott férjét átölelő nőt látjuk, míg a bal oldalon egy követ dobni készülő nő áll, ezúttal a másik nőalak nélkül ${ }^{75}$ (14. kép). Abban, hogy a hangsúly az anyját megbosszuló lány helyett a férje haláláért bosszút álló feleség történetére került, közrejátszhattak Székely müncheni múvésztársainak és tanárainak korrekciói, tanácsai is: amint egy naplóbejegyzéséből kiderül, Piloty például azt javasolta, hogy a kardot emelő nőalakot helyezze a kép középpontjába. ${ }^{76}$

Székely tehát festménye kompozíciójának megalkotásakor egy több száz éves irodalmi toposzból (az egri nők vitézsége általában - s ezen belül a két konkrét történet) merített ihletet. A toposz 19-20. századi népszerüségét jelzi, hogy számos, Székely festményénél későbbi hazai képzőművészeti alkotáson ${ }^{77}$ is találkozunk vele.

Az egri asszonyoknak a történeti forrásokban és néhány költeményben kirajzolódó harcias, férfias, néha kegyetlen és vérengző képétoő ${ }^{78}$ eltérően azonban Székely festményén - mint Cséka Károly egri rajztanárhoz írott leveléből kiderül - még a harcoló asszonyokban is női sajátosságaikat kívánta hangsúlyozni: „Hanem most még arra is kérlek, hogy képemet egy kissé magyarázd meg a néhány ott irányadó úri emberek- és asszonyoknak, ha tudniillik megtámadnának.

A felfogásnál irányadó volt a nő tevékenysége motíválása, az, hogy nőies maradjon; azáltal tör-

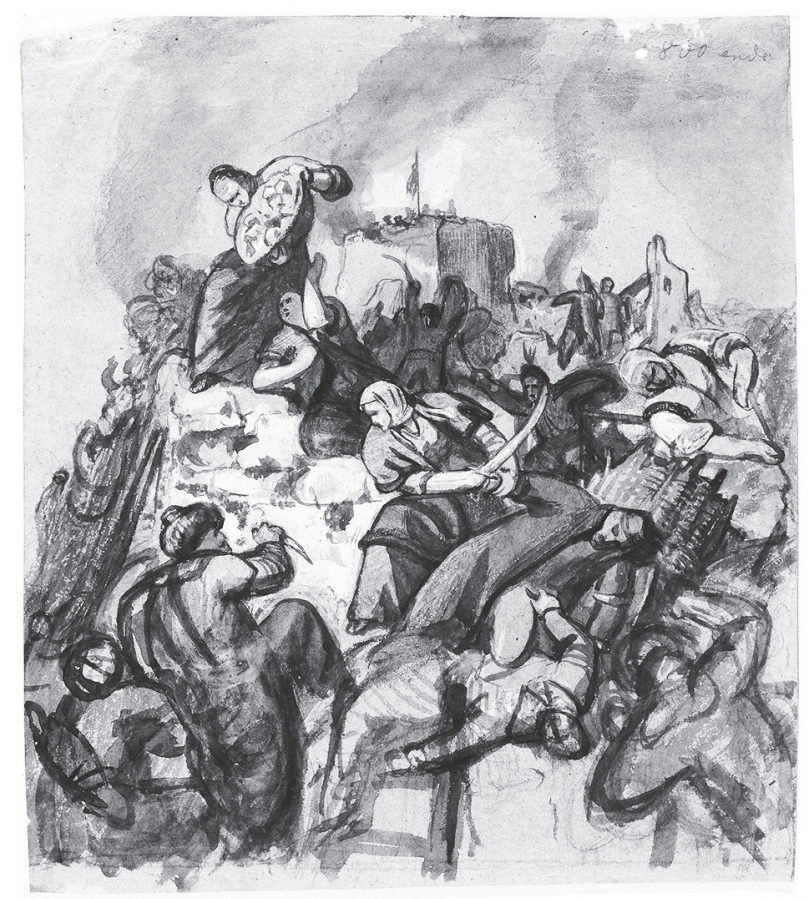

13. Székely Bertalan: Vázlat az Egri nókhöz, 1860. Magyar Nemzeti Galéria, Grafikai Osztály, ltsz. 1917-352

tént, hogy a dühöt is a szeretetből származtattam - a férjét bosszulván meg; a bal kéz a haldokló férj kezét tartja, a jobbja ezen kézből átvett kardot.

A mozdulateljárásból azon perc választatott, midőn már lesújtott egy törököt és műve eredményét borzadva, de triumphálva nézi... [...]...A nő hősiességét növeli az is, hogy elöl az ellen, hátul a tüz, - a két baj között is megállja a helyét. Azonkívül. hogy megette a tüzet ledobó gruppig intervallum van, mi azáltal, hogy ő csak kevesed magával van itt, őt hősiessé teszi. És utoljára az is, hogy a kosarat átadó nő a bátorságnak egy kevesebb árnyalatával (nuance) bír."79 A megfogalmazásban ugyanakkor kétségtelenül van egy sajátos ambivalencia: a nő borzadva, de diadalmasan szemléli tettét, vagyis a gyenge nő bár elirtózik a véres látványtól, egyszersmind élvezi is győzelmét, éppúgy, mint a harcoló férfiak.

Úgy tünik, Székely elérte célját, mert a festményt a Fővárosi Lapok munkatársa, Kazár Emil (1843-1922) hírlap- és regényíró is - aki szintén ismerte a férjét megbosszuló nő történetét - a müvész szándékának megfelelően értelmezte: „Kitünő történeti festőnk Székely Bertalannak Egri nőiről szólunk, mely miután Bécsben is ki volt állítva s feltünést okozott, most a képzőművészeti társulat kiállításában vendégszerepel, s melyről most már bizonyosul mondhatjuk, hogy nemsokára legilletékesebb helyére, a nemzeti muzeum képtárába kerülend, és pedig a mű tárgyának: a régi egri nők- 
nek méltó utódai, a mostani egri nők áldozatkészsége s mübuzgalma folytán.

1552-ben, midőn a török majdnem két száz ezerrel ostromlá az alig két ezer védette Egert, a várbeli nők hősies elszántsága is segitett a férfiaknak a vár megtartásában. A nők rohamok alkalmával forró vizet, olvasztott szurkot, súlyos köveket ontottak az ostromlók fejére; s volt példa, hogy nő s leány, karddal kezében űzte vissza a vár fokára feltörekvő ellenséget, volt, hogy a halálos sebbel lerogyó férj kezéből a nő ragadta ki a fegyvert, hogy boszut álljon megölt hitveseért. Íly tárgy, egy ízléstelenebb s kevésbbé gondolkodó festőnek mint Székely, talán olcsó hatás eszközeivel kinálkoznék. Hősködő amazonokat festene, kik semmi más motívumból, mint hogy vitézkedjenek, kardot csörgetve, talán pánczélosan s piros csizmában sarkantyúsan csoportosulnának a vár falára. Székely máskép fogta fel a dolgot; ô a nő hősiességét is nőiesnek tüntette föl, s ezzel művészibb és valódibb hatást biztositott magának.

A hat láb magas kép előterében, a törököktől megmászott vagy megmászni próbált vár fokán, teljes világitásban áll az egri nő. Kezében a hirtelen csapás után görcsösen tartott kard van, - de férje kardja, ki épen lerogyott s örök álomra hunyta szemét, kinek elhalt megnehezült kezét balkezében tartja nője még, míg jobbjával a tőle elejtett kardot ragadta el; azt a törököt sujtotta vele, ki férjét elejté, s így a nő hősiességét a szerető szív boszúja irányozza...[...]... A központtól balra két nő egy kővel rakott kosarat emel, (a szélső szép festői mozdulattal,) jobbra ismét nőket látunk, kik tüzet készülnek az ostromlókra dobni. Van férfi-alak is, $\mathrm{s}$ a nőket seholsem látjuk valami vérengző foglalkozásban...

$$
\text { - á }-\mathrm{r}-{ }^{\text {“80 }}
$$

A leírás megítélésem szerint oly mértékben egybevág Székelynek a festményról írt magyarázatával, hogy nem zárható ki, nézeteit a cikkíróval is megosztotta, s az egyetértett a festő értelmezésével.

Az egri nők tettének hazafiasságát - mint láttuk már a legkorábbi források is hangsúlyozták. ${ }^{81}$ Ezt az indíttatást Székely is kiemelte: „Egri nők (értelme: a nők is tehetnek a hazáért)" - írta a tervezett festményről Kuun Kocsárd Hunyad megyei főispánnak 1859 körül Münchenből küldött, anyagi támogatást kérő levelében. ${ }^{82}$

A nők hazafiasságának megítélése a 19. században sajátos átalakuláson ment keresztül. Az aszszonyok - ahogy Dukai Takách Judith A' Hazához címü, a női vitézség toposzát egyébként szemléletesen lefestő versében hangsúlyozta - már nem fegy-

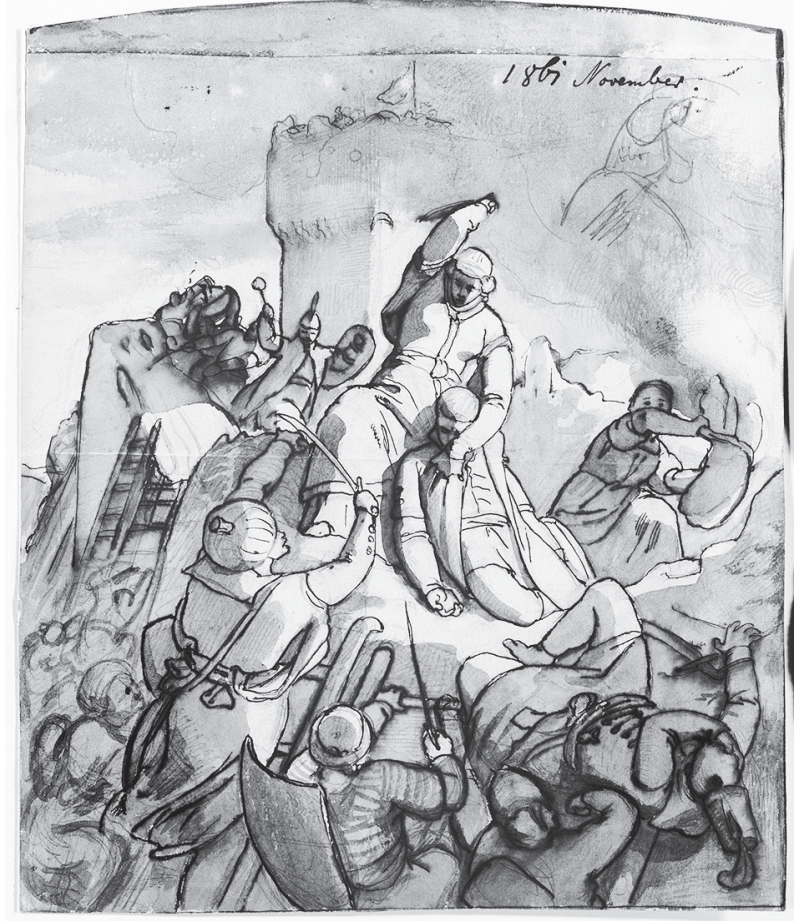

14. Székely Bertalan: Vázlat az Egri nókhöz, 1861. Magyar Nemzeti Galéria, Grafikai Osztály, ltsz. 1917-362

verrel, hanem a kultúra támogatásával kívántak harcolni a hazáért:

„Nem engedi ugyan az én gyenge nemem

Hazámért eggy ollyan áldozatot tennem, Melly vérbe kerülne.

Sem azt hogy eggy vitéz Amazon' módjára,

Lelkem az ellenség erős táborára

Ütvén, felhevülne.

Vagy mellyemet én is pánczéllal övedzem,

Sisakot viseljek és így megütközzem,

Menvén ellenségre.

'S oldalamra bosszúálló fegyvert kössek,

Hogy így az ártatlan vérrel földet fessek,

Vagy jussak végemre.

$\cdots$

Én a' szelid Múzsák' hív társaságában

Adom magam, 's ezek' szent barátságában

Boldogabb életem.

Ezekkel zengem el csekély Dalaimat,

Oltárodra Hazám hív áldozatimat

Ezekkel tétetem..." 83

A „honleányok" és az asszonyok feladatai között a század eleje óta egyre jelentősebb helyet foglalt el a nemzeti művelődés - nyelv, irodalom, képzőmüvészet, színjátszás - támogatása. ${ }^{84}$ Egyes asszonyok vagy nőegyletek részt vettek a nemzet kiemelkedő tagjainak tiszteletére állítandó szobrok költségeinek előteremtésében, a nemzeti múlt eseményeit bemu- 
tató festmények készíttetésében, ${ }^{85}$ kulturális közintézmények létrehozására irányuló gyűjtésekben, a közgyưjtemények állományának gyarapításában. ${ }^{86}$ A 19. század második felében számos jótékonysági célú művészeti, iparművészeti kiállítást rendeztek - elsősorban főrangú - asszonyok felhívására és szervezésében. ${ }^{87}$
Ezekhez a törekvésekhez kapcsolódott az Eger és Vidéke Olvasó és Jótékony Nőegylet, amely megvásárolta, majd - mint a kép hátoldalán olvasható feliratból kitünik - 1868-ban a Nemzeti Múzeumnak ajándékozta Székely Bertalan Egri nők című festményét, mely azóta nemcsak az 1552-ben a törökök ellen harcoló, hanem az 1860-as években a nemzeti kultúra felemeléséért tevékenykedő egri asszonyok hazafiasságát is hirdeti. ${ }^{88}$

\section{JEGYZETEK}

1 Bodola 1908, 53-60; Divinyi 1938, Sugár 1971, Sugár 1974, H. Szilasi 2002; Bitskey István: Az egri vár viadala a XVI-XVII. századi irodalomban, Agria 38. 2002, 189-201; Lókös 2004; Bitskey 2006; Lókös 2006; Lókös 2008; Lőkös 2008/1; Obsidio 2008.

2 Lókös 2008, 69.

3 Bitskey 2006, 75-86; „,A hiteles történeti adatok csak két nőnek őrizték meg a nevét a vitézkedők közül: egyik elesett az ostromban, ez Vas Ferencz anyja, másik Kocsis Gáspár felesége, kiről azt mondja Dobónak Nádasdy főkapitányhoz intézett jelentése: »Margaretha consors Casparis Kochys una cum marito suo per pixidem et lapides vulnerata, merentur flor. 4., et maritus vestem.«" Bodola 1908, 60.

4 Istvánffy Miklós Magyarok dolgairól írt históriája. Tállyai Pál XVII. századi fordításában. 1/2. 13-24. könyv. Budapest 2003, 219-220.

5 Tájékozó szó az Eger 1552-iki ostromát ábrázoló képhez. Eger 6. 1868, 14. szám, április 2., 128-130.

6 Lókös 2008, 160-161. Az eredeti olasz szöveget 1.: Obsidio 2008, 57-58. Ascanio Centorio degli Hortensi: Commentarii della Gverra di Transilvania... in Vinegia..., 1566, Lib. 5, 223-224.

7 Lókös 2008, 160-161.

8 Szekfü Gyula: Két historiographus Castaldo erdélyi seregében. Századok 48. 1914, 17-33.

9 „Egy ilyen lelkiismeretlen, megbízhatatlan s az országban sem járt idegen szerzőnek az érdeklődést felcsigázó romantikus részletleírásai távol állanak tehát az igazságtól és Tinódi Sebestyén minden fölös pátoszt kerülő, a történeti hűséghez ragaszkodó históriás énekétől, s az említett események hitelt nem érdemlők." Sugár 1974, 32. Centorióról l. még: Lókös 2008, 155; Obsidio 2008, 12-13.

10 Elképzelhetö, hogy Centorio a korban népszerủ efemer kiadványtípusból, a török háborúk eseményeiről a nyugat-európai lakosságot tájékoztató 1-2 lapos hírlevelek (Relatio, Newe Zeitung, Avviso) valamelyikéből vette az adatokat.

11 Libro di M. Gio. Boccaccio delle Donne illustri, Tradotto per Messer Giuseppe Betußi... In Venetia 1547.

12 Lydia Miklautsch: Wozu Heldinnnen? In: Johannes Keller, Florian Kragl Hrsg.: Heldinnen (10. Pöchlarner Heldenliedgespräch). Wien 2010, 11-17.

$13 \mathrm{Az}$ ostromok idején a kapitány és a tisztek feleségei általában nem voltak a várakban.

14 Resolvtio Brevis Orationvm M. T. Ciceronis Secvndvm Cavsarvm Genera, Orationum partes, materias, in Eloqventiae Stvdiosorvm ... Avtore Melchiore
Ivnio... [Wittenberg] 1594, 328. Vö.: Pauszaniasz: Görögország leírása, ford.: Muraközy Gyula. Attraktor, Máriabesnyő-Gödöllő 2008, 1. kötet, IV. könyv, 272.

15 Libro di M. Giovanni Boccaccio Delle Donne Illustri. Tradotto di Latino in Volgare per M. Giuseppe Betussi, con una giunta fatta dal medesimo, D'altre Donne Famose. E vn'altra nuoua giunta fatta per M. Francesco Serdonati. D'altre Donne Illustri. Antiche e moderne. Con due tauole vna de nomi, e l'altra delle cose più. In Fiorenza, Per Filippo Giunti. 1596. 605-606. A fegyverrel harcoló vitéz magyar nő típusát ábrázolta Serdonati az egri nők története előtt is: említést tett egy asszonyról, aki Székesfehérvár 1543. évi török ostromakor egy kaszavágással két janicsár fejét vágta le. Az ismereteim szerint a hazai szakirodalomban ilyen összefüggésben még nem tárgyalt forrásról részletesen 1: Papp Júlia: Donne Vngare. Kézirat. Megjelenés alatt az Irodalomtörténeti Közleményekben.

16 Chronologia Oder Historische beschreibung aller Kriegsempörungen vnd belägerungen der Stätt vnd Vestungen auch Scharmützeln vnd Schlachten so in Ober vnd Vnder Vngern auch Siebenbürgen mit dem Türcken von A. 1395. biß auff gegenwertige Zeitt gedenckhwürdig geschehen. Zusammen verfast und mit fleiß beschriben durch $\mathrm{Hi}$ eronymum Ortelium Augustanum. Nürnberg 1602. 23.

17 Gaspare Ens: Rerum Hungaricarum historia, novem libris comprehensa... Coloniae Agrippinae 1604, 223; Thuanus (Jacques-Auguste de Thout): Historiae Sui Temporis. Paris 1606. Tomus 1. Liber X. 293; Ortelius redivivus et continuatus oder der Ungarischen Kriegs-Empörungen historische Beschreibung... Von dem 1395 bis in das 1607 Jahr... Durch den berühmten Herrn Hieronymum Ortelium Augustanum...Mit einer Continuation von dem 1607 bis an das 1665 Jahr vermehret durch Martin Meyern. Frankfurt am Main 1665, 87. (magyarul Lókös 2008/1, 129-130); Hungarische / Siebenbürgische / Moldau- Wallach- Türck- Tartar- Persian- und Venetianische Chronica, oder Außführlich / Wahrhafftige Beschreibung / deß Königreichs Hungarn... Aus vielen bewehrten Scribenten zusammen getragen und hervor gegeben durch Johannem Gradelehnum. Franckfurt am Mayn... 1665, 156-157.

18 Thomas Lansius: Consultatio de principatu inter provincias Europae. Tübingen 1613, 373-375.

19 Lókös 2008, 255.

20 Hungarisch-Türkische Chronick / Das ist / Curiöse und dabey kurz-gefaßte Beschreibung alles des jenigen / Was sich Vom Ersten grausamen Kriegs-Zug der Türcken wider das Königreich Hungarn ... Nürnberg 1685, 128129. Vö.: H. Szilasi 2002, 288. 
21 Georg Krekwitz Totius Regni Hungariae superioris et inferioris accurata descriptio (1686). A szöveget 1 . Obsidio 2008, 109. Vö.: Lőkös 2004, 272.

22 Mathias Miles: Siebenbürgischer Würg-Engel oder Chronicalischer Anhang der 15. Seculi nach Christi Geburth aller theils in Siebenbürgen theils in Ungern und sonst Siebenbürgen angräntzenden Ländern fürgelauffener Geschichten... Nagyszeben 1670. Vö.: Lőkös 2004, 272; Obsidio 2008, 105-106; Lókös 2008, 265.

23 Christiani Schesaei Saxonis Transsilvani Rvinae Pannonicae Libri Qvator... Ex editione Wittemberg. Ann. MDLXXXI recvsi. Opera Iosephi Caroli Eder. Cibinii MDCCXCVII [1797], ebben: Lib. IV. 192. Vö.: Hegedüs István: Schesaeus Ruinae Pannonicae czímű epikus költeménye. Értekezések a nyelv- és széptudományok köréből. XXIII. kötet. 5. szám. Budapest 1916, 10.

24 Herzhaftigkeit der Frauenzimmer. Mannigfaltigkeiten. Eine gemeinnützige Wochenschrift mit Kupfern. Vierter Jahrgang. Berlin 1773, 442-444.

25 Allergnädigst privilegierte Anzeigen aus sämmtlich-kaiserlich-königlichen Erbländern herausgegeben von einer Gesellschaft. Vierter Jahrgang, III. Stück, Wien, den 19. Jenner 1774, 23-24; Ungrisches Magazin, oder Beyträge zur vaterländischen Geschichte... Erster Band, Preßburg, 1781, 251-253; Kurzgefasste Geschichte der Ungern von den ältesten, bis auf die itzigen Zeiten... von Karl Gottlieb v. Windisch. Neue, vermehrt und verbesserte Auflage, Preßburg 1784, 355-356; Länder- und VölkerMerkwürdigkeiten des österreichischen Kaiserthumes, Von Dr. Franz Sartori, Zweyter Theil. Wien 1809, 143-145; Leopold Chimani: Vaterländischer Jugendfreund. Ein belehrendes und unterhaltendes Lesebuch zur Veredlung des Herzens, Beförderung der Vaterlandsliebe und gemeinnütziger Kenntnisse für die Jugend des österreichischen Kaiserstaates, Fünfter Theil. Wien 1814, 37-39.

26 Kis János: Ifjúság barátja, vagy hasznosan mulattató darabok a' két nembéli ifjúság számára. Pesten 1816, II. kötet, 182-184.

27 Die Geschichten der Ungern und ihrer Landsassen. Sechster Theil. Ungarn's Fall. Erzählet von Dr. I. A. Fessler. Leipzig 1823, 796-797; Joseph von Hammer: Geschichte des osmanischen Reiches... III. Band. Pest 1828, 310-311; Meynert 1846, 202-203.

28 Rajcsányi János: Magyarország Története az Első Ifjuságnak. Pesten 1843, 124; Horváth Mihály: A magyarok története. Harmadik szakasz. Pápán 1844, 79-80; Horváth Mihály: A magyarok története az ifjúság számára. Harmadik, újan dolgozott kiadás. Második rész. Pesten 1845, 14-15; Horváth Mihály: A Magyarok története. A bölcsészettanuló ifjuság számára. Bécsben 1847. Bizományban Geibel Károly könyvárusnál Pesten, 273-274.

29 Kubinyi-Vahot 1854, 15-16.

30 Kubinyi-Vahot 1854, 11.

31 Kubinyi-Vahot 1854, 15-16.

32 Kubinyi-Vahot 1854, 17.

33 Magyar Néplap 2. 1857, 60. szám, 478-479; 61. szám, 486-488.

34 Magyar Néplap 2. 1857, 60. szám, 479.

35 Magyar Néplap 2. 1857, 60. szám, 479.

36 Magyar Néplap 2. 1857, 61. szám, 486.

37 Magyar Néplap 2. 1857, 61. szám, 486.

38 Magyar Néplap 2. 1857, 60. szám, 478.
39 Remellay Gusztáv: Multunk hölgyei. Hazai történelem. Regényes krónika-modorban magyar hölgyek számára. I-II. Pest 1860-1861.

40 Vasárnapi Ujság 7. 1860, 31. szám, július 29., 371.

41 Triumphus Gloriosus sive Novem Stephanorum pro Agria Strenue pugnantium gloriosa defensio ac victoria. Honori ... Stephani Telekesi ... Dum annuos Palladis labores praemijs remuneraretur. A ... ArchiEpiscopalis gymnasij Agriensis Juventute in Scenam datus. Leutschoviae [Brewer, 1700]. Obsidio 2008, 110. Vö.: Kilián István: Törökverő magyarok az iskoladrámákban. In: Az Egri Múzeum Évkönyve XI-XII. Eger 1974, 177-180; Staud Géza: A magyarországi jezsuita iskolai színjátékok forrásai III. 1561-1773. Budapest, 1988. 129130; Kilián István: A piarista dráma és színjáték a XVIIXVIII. században. Budapest, 2002. 97; Obsidio 2008, 19. A színdarabot Székely Bertalan Egri nők című festménye kapcsán - téves adatokkal - említi: Sinkó 1995, 235.

42 Jezsuita iskoladrámák (Ismeretlen szerzők): Programok, színlapok. Szerk.: Varga Imre. [Régi Magyar Drámai Emlékek XVIII. század, 4/2.] Budapest, 1995. 10841085. A német szöveget 1.: Obsidio 2008, 124.

43 Vers-koszorú, mellyet az Új mértékre vett, s üdövel megegyengetett, és későbben készült verseiből kötött Erdélyi, Baróthi Szabó Dávid... Első szakasz. Kassa 1786, 145-149.

44 Családi lapok. Tudományos és szépirodalmi folyóirat, a vallás-erkölcsi müveltség $s$ kath. hitélet emelésére 6. $1857 / 2.308$.

45 Bodola 1908, 53-60; Székely 1999, 138.

46 L.: Divinyi 1938, 28.

47 Idézi: Kubinyi-Vahot 1854, 20.

$48 \mathrm{Az}$ egri várban.

„Itt víttak a' hon bátor hölgyei;

Itt onta vért a' nő hív férje mellett,

Míg férj és nő utósót nem lehellett,

Mint egy sujtott hazának szentei..." Pájer 1847, 187.

49 Pájer 1847, 260-263.

50 Dr. Lányi Károly: Magyar nemzet történetei képekkel a nép számára. Pozsony 1846, 172.

51 Ifj. Szabó Pál fiumei kereskedő és újságíró, a Magyar Kereskedelmi Társaság igazgatója 1846 körül a társaság pénztárhiánya miatt külföldre szökött. Párizsban nevét Boldényire változtatta.

$52 \mathrm{La}$ Hongrie Ancienne et Moderne. Histoire, Arts, Littérature, Monuments par... M. J. Boldenyi. Paris 1851, 152-153. J. b. 1.: Trichon.; Boldényi J.: Ungern i pittoreskt, historiskt, litterart, artistiskt och monumental hauseende... Stockholm 1852, 130-131. oldalak között. Jelzés nélkül. Az 1852-ben Pistojában megjelent olasz nyelvü kiadás nem tartalmazza az egri nőket ábrázoló litográfiát.

53 Edwin Lawrence Godkin: The History of Hungary and the Magyars. From the earliest Period to the close of the late War. London 1853, 169, 171.

54 Magyar Néplap 2. 1857, 61. szám, 486; a Magyar Néplapnál munkatársként dolgozó Remellay Gusztáv által szerkesztett Ifjúság Lapja 1864, 42. szám, 669; Hírmondó 1868, 29. szám, 341. Vö: Révész 2010.

55 Kiss Bálint: Eger ostroma. Litográfia, MNM TKCS, ltsz.: 2523 T. Vö.: Szabó Júlia, Széphelyi F. György szerk.: Magyar múvészet 1830-1870. II. kötet. Budapest 1981, 123. tétel, 262; Révész 2000, 555. 
56 Eger várának hősi megvédése Dobó és bajtársai és az egri nevet velök együtt kivívott magyar nők által, 1552-ben. E kép tervezője s kiadó-tulajdonosa: Vahot Imre. Eredetijét rajzolta: Vizkelety Béla, 1860-ban. IV-ik történeti múlap a Napkelethez. Vö.: Révész 2000.

57 Magyar történelmi képcsarnok. A Vizkeleti B. által rajzolt s Vahot Imre által kiadott „Hunyadiház diadalünnepe”, - „Mátyás az igazságos”, - „Bátori István lengyel király bevonulása Krakkóba”, - „Egervár hősi megvédése" czímű képek történeti és költői magyarázata. Kuliffay Ede, Lisznyai Kálmán, Székely József, Szilágyi Sándor- és Vahot Imrétől. Szerkesztette Vahot Imre. Pest, 1860. 89-90. A szöveg Vahot újságjában is megjelent: Napkelet 4. 1860, 1. szám, 11-13; 2. szám, 25-29; 3. szám, 42-46. A két vitéz nő tettének leírása: 3 . szám, 44.

58 Székely 1962, 150.

59 Sinkó 1995; Bakó 2002. A festmény reprodukcióját tartalmazó korábbi kiadványokról: Révész 2010.

60 Die Ausstellung des Vereines der bildenden Künste. K-x: Székely: Weiber von Erlau 1552. Ungarischer Lloyd. 1868. február 4. (Nr. 34) o. n. Vö.: Székely 1999, 138; Bakó 2002, 312-313.

$61 \mathrm{Az}$ Akadémiai Könyvtár (a továbbiakban MTAK) Kézirattárában lévő Székely-hagyaték egyik vázlatfüzetének a bejegyzése szerint pl. ismerte az Aus vier Jahrhunderten - Mittheilungen aus dem Haupt-Staatsarchive zu Dresden (Leipzig. Tauchnitz 1857) című kiadvány első kötetét, amely tartalmaz egy, az 1566. évi szigetvári ostrommal és Zrínyi hősiességével foglalkozó írást. MTAK Kézirattár, Ms. 5006/13. 92v. Ezt minden bizonnyal a Zrínyi kirohanását ábrázoló festmény kompozíciójának kialakításához használta.

62 Horváth 1844, 79-80.

63 Székely 1999, 138.

64 Sinkó 1995, 236.

65 Bakó 2002, 313.

66 Szépmúvészeti Múzeum - Magyar Nemzeti Galéria (a továbbiakban MNG), Grafikai Osztály, ltsz.: 1917351. Vö.: Székely 1999, 134 (57. tétel).

67 Székely Bertalan: Ifjúkori napló. MNG Grafikai Osztály, ltsz.: 1915-1760, 13v (14).

68 MNG Grafikai Osztály, ltsz.: 1917-359. Vö.: Székely 1999, 134 (58. tétel).

69 Székely Bertalan: Ifjúkori napló i. m. 171, alsó kép.

70 Lehet, hogy csupán véletlen egybeesés, de az is lehet, hogy Székely ismerte azt az 1846-ban Pesten megjelent német nyelvű történeti munkát, melyben nem csak a két hősnő története, hanem a "Schild und Schwert" kifejezés is szerepelt: "Selbst die ungarischen Frauen drängten sich in die Reihen der Feinde, Eimer konchenden Wassers und fiedenden Oeles über die Häupter der Feinde ausgießend. Eine junge Frau, an deren Seite ihr Gatte fiel, und die von ihrer Mutter aufgefordert wurde, den Todten $\mathrm{zu}$ bestatten, antwortete: "nicht eher, als bis ich ihn gerächt, « und dies sagend, ergriff sie des Gefallenen Schild und Schwert, und stieß mit demselben die Feinde nieder. Eine Tochter, neben welcher die mit einer schweren Steinlast bewaffnete Mutter erschossen wurde, entriß der Sterbenden den Stein, und zerschmetterte, ihn herab schleubernd, zwei Türken." Meynert 1846, 202-203.
71 Székely Bertalan: Ifjúkori napló i. m. 173. „Ideen die mich 1861 beschäftigten. Also Übergang die Erlauer Weiber mit denen ich mich seit 1857 befasse." I. m. 171.

72 MNG Grafikai Osztály, ltsz.: 1917-363. Vö.: Székely 1999, 135 (60. tétel).

73 MNG Grafikai Osztály, ltsz.: 1917-352. Vö.: Székely 1999, 135 (59. tétel).

74 Sinkó 1995, 236.

75 MNG Grafikai Osztály, 1tsz.: 1917-362.

76 Bakó 2002, 317.

77 Pl. Körösfői Kriesch Aladár: Dobó István az egri nők segítségével megvédi Eger várát a török ellen, 1896, olajfestmény, Eger, Városháza; Zala György: Eger ostroma, relief, eredetileg a milleniumi emlékművön I. Ferdinánd szobra alatt, ma az egri várban, http://www. kozterkep.hu/ /17028/\#; Stróbl Alajos: Dobó, 1907, Eger, fötér; Tarr István - Illés Gyula: Eger ostroma, dombormü, 1952, egri vár. Vö.: H. Szilasi 2002, 297-300.

78 A mégoly nemes célért is harcoló nők brutalitásának ábrázolása - elég ha az itáliai festőnőnek, Artemisia Gentileschinek (1593-1653) az ószövetségi Juditról (Firenze, Uffizi) és Jahelről (Budapest, Szépművészeti Múzeum) készült festményeit említjük - a képzőmüvészettől sem volt mindig idegen.

79 Székely 1962, 149. Korábban 1.: Lázár Béla: Zichy Mihály élete és művészete. Budapest, 1927, 161-162.

80 Vasárnapi Ujság 15. 1868, febr. 16. 7. szám, 77-78. Kazár Emil írta azt az 1868-as cikket is, melynek kivágata az MTAK Kézirattárában őrzött Székely-anyagban található: Két festvény a képzőművészeti társulat csarnokában. (Wagner Sándortól és Székely Bertalantól.) „Az egri nők hősiessége (1552-ben) eléggé ismeretes. Oly tárgy, mely könnyen bombasztikus szélsőségekre ragadhatja a festőt. A fölületes hatást könnyen lehetett volna elérni: ha a müvész oda fest egy csoport nőt, különböző harcias foglalkozás közt, s benépesít velök egy nagy darab vásznat, fest bájos arcokat, gömbölyü karokat, melyekkel kardot, láncsát forgatnak. Ez igen magvatlan cselekményt mutatott volna, de könnyebben hatást kelt... [...]... „A föalak egy nő a bástyafokon. Nem harcias amazon, ki páncélosan sisakosan áll ott, s küzd, mint egy csatár. A festész egész gyöngédséggel, teljes nőiességében állította oda, ki míg jobbjában kardot emel, balja gyöngéden egy leroskadt páncélos kezét fogja, meglehet férjeét. Talán a másik pillanatban ő is oda roskad, mert lábai alatt, a várfokon törökök másznak föl. Ez alak előállítása és működése jó fölfogással magyarázza a helyzetet: az elkeseredett lelkesültséget, melyet a veszély gyürüi környeznek; a nőiességet is kitünteti, a harcot gyöngéd helyzettel hozva össze." ...[...]... A központtól balra két nő egy kővel rakott kosarat emel...jobbra ismét nőket látunk, kik tüzet készülnek az ostromlókra dobni. Van férfialak is, s a nőket seholsem látjuk valami vérengző foglalkozásban." MTAK Kézirattár, Ms 5007/3.

81 Centorio 16. századi könyve mellett a haza megvédésének fontosságát az 1700-ban az egri jezsuita kollégiumban előadott színdarab is kiemelte: „Filia Matri proxima saxum Sangvi nolentum, vindicta ardens in hostes dejecit, duos interemit, aliquot alios gladio trucidavit, passimque circum currens ad defendendam Patriam Heroica voce omnes hortabatur." Obsidio 2008, 110. Az egri nők 
vitézségének hazafias jellegét hangsúlyozták a 19. századi szerzők is: „És lőnek jelenések, mellyeknél magasan feldobog az ember és hazafi szíve." Horváth 1847, 273-274.

82 Bakó 2002, 310, Székely 1962, 148.

83 Aspasia. Szerkeszteté Kovacsóczy Mihály. Pesten, 1824. 42.

84 A pest-budai „Jóltevő Asszonyi Egyesület” felhívására fordította le 1818 körül Szemere Pál (1785-1861) Theodor Körner (1791-1813) Zrínyi címü drámáját, s a nőegylet költségén jelent meg Pyrker János László (1772-1847), a későbbi egri érsek verseskötete: Perlen der heiligen Vorzeit. Gesammelt durch Johann Ladislav Pyrker. Ofen 1821. Gedruckt, auf Kosten des Ofner wohlthätigen Frauen-Vereines.

$85 \mathrm{Az}$ asszonyi hősiességhez kapcsolódott az a felhívás, mellyel 1862 májusában gr. Zichy Lívia, gr. Zichy Nándorné „Fehérvármegye müvelt lelkű fiai- és leányaihoz" fordult, hogy Székely Bertalan Dobozit és feleségét ábrázoló festményét vásárolják meg a Nemzeti Múzeum számára. Vö.: Szőke Annamária: „....ostoba angyalkákkal játszik üres óráiban." A kutató és elmélkedő Székely Ber- talan-kép a kritikában és a művészettörténet-írásban. In: Székely 1999, vö. http://arthist.elte.hu/Tanarok/SzoekeA/ fulltexts/Sz\%E9kely01.htm

86 Rumy Gizella például 1859-ben 34 forintot és két aranyat ajándékozott Dunaiszky László (1822-1904) készülő Lendvay-szobrára, 1861-ben és 1881-ben pedig régészeti leleteket, illetve iparmüvészeti tárgyakat adományozott a Nemzeti Múzeumnak. Vö.: Papp Júlia: A Rumyserleg története. Budapest 2008, 45-46.

87 Gr. Zichy Pál Ferencné, Kornis Anna kezdeményezte például az 1876-ban a Károlyi-palota négy termében a nagy dunai árvíz károsultjainak megsegítésére rendezett „múipari és történelmi emlék-kiállítást."

$88 \mathrm{Az}$ 1860-as évek elején Remellay Gusztáv írásával (Nefelejts, 1860, 491) induló akcióról 1.: Sinkó 1995, 236; Révész 2000, 556.; Bakó 2002, 319. A nőegylet tagjai között kialakult vitát, mely az egylet vezetőjének, a müértő Nánásy-Csernyus Amáliának befolyására a kép megvásárlásával ért véget, illetve a vitához kapcsolódó hírlapi "feleselést" kritikájában Kazár Emil is megemlítette, 1. Vasárnapi Ujság 15. 1868, 7. szám, febr. 16., 78.

\section{RÖVIDÍTVE IDÉZETT IRODALOM}

Bakó 2002 - Bakó Zsuzsanna: Egy „nemzeti toposz” születése. Gondolatok Székely Bertalan Egri nők című képe kapcsán. Agria 38. 2002, 309-324.

Baróti 1786 - Vers-koszorú, mellyet az Új mértékre vett 's üdövel megegyengetett, és későbben készült verseiből kötött Erdélyi, Baróthi Szabó Dávid... Első szakasz. Kassa 1786.

Bitskey 2006 - Bitskey István: „Vitézeket írja krónikájába” (Eger diadala az irodalomban). In: Bitskey István: Mars és Pallas között. Múltszemlélet és sorsértelmezés a régi magyar irodalomban. Debrecen 2006, 75-86.

Bodola 1908 - Bodola Gyula: Dobó István a magyar költészetben. Kolozsvár 1908.

Divinyi 1938 - Divinyi Mihály: Eger a magyar költészetben. Budapest 1938.

H. Szilasi $2002-H$. Szilasi Ágota: Az egri vár és hősei a képzőművészetben. „Agria, Munitissima Hungariae Superioris propugnaculum sepe a Turca tentatum..." Agria 38. 2002, 285-308.

Kubinyi - Vahot 1854 - Magyar- és Erdélyország képekben. IV. kötet. Kiadják és szerkesztik: Kubinyi Ferencz és Vahot Imre. Pest 1854.

Lókös 2004 - Lőkös Péter: Eger 1552-es ostromának ábrázolása a 16-17. századi erdélyi szász és szepességi német irodalomban. Agria 40. 2004, 261-293.

Lókös 2006 - Lókös Péter: Egy XVII. századi erdélyi szász krónikás az 1552-es egri ostromról. Honismeret 34. 2006/1, 39-45.

Lókös 2008 - Lôkös Péter szerk.: „Jó Dobó miatt sok terekök vesznek". 16-17. századi költők és krónikások az 1552-es egri ostromról. (Eötvös Klasszikusok 86. kötet) Budapest 2008.

Lókös 2008/1 - Lókös Péter: Az 1552-es egri ostrom leírása Hieronymus Ortelius krónikájában. Agria Irodalom Múvészet Kritika 2. 2008/1, 124-133.
Meynert 1846 - Geschichte Oesterreich's, seiner Völker und Länder, und der Entwickelung seines Staatenvereines von den ältesten bis auf die neuesten Zeiten. Von Dr. Hermann Meynert. Fünfter Band. Erste Abtheilung. Pesth 1846.

Obsidio 2008 = Péter Lókös, Gábor Tüskés Hrsg.: Obsidio Agriae anno 1552. Texte zur Rezeption eines ungarischen Geschichtsstoffes. Eger 2008.

Pájer 1847 - Pájer Antal versei. Pest 1847.

Révész 2000 - Révész Emese: Eger várának hősi megvédése. In: Mikó Árpád - Sinkó Katalin szerk.: Történelem Kép. Múlt és múvészet kapcsolata Magyarországon. Kiállítási katalógus. Magyar Nemzeti Galéria, Budapest 2000, 555-556, (X-12).

Révész 2010 - Révész Emese: Látta-e már valaha az Egri nőket? In: „Az eszményi szépség apostola.” Művészettörténeti tanulmányok. (Székely Bertalan Müteremház Füzetek 8.). Szada 2010, 35-41.

Sinkó 1995 - Sinkó Katalin: Székely Bertalan: Egri nők 1867. In: Sinkó Katalin szerk.. Aranyérmek, ezüstkoszorúk. Művészkultusz és müpártolás Magyarországon a 19. században Kiállítási katalógus. Magyar Nemzeti Galéria, Budapest 1995, 235-236.

Sugár 1971 - Sugár István: Az egri vár és viadala. Budapest 1971 .

Sugár 1974 - Tinódi egri históriás énekei. A bevezető tanulmány, a szövegátírás és a jegyzetek Sugár István munkája. Eger 1974.

Székely 1962 - Székely Bertalan válogatott müvészeti írásai. Válogatta, a bevezetést és a jegyzeteket írta: dr. Maksay László. Budapest 1962.

Székely 1999 - Nagy Ildikó szerk.: Székely Bertalan (18351910) kiállítása. Magyar Nemzeti Galéria 1999. szeptember 30 - 2000. január 30. Magyar Nemzeti Galéria, Budapest 1999. 


\section{HISTORICAL SOURCES OF BERTALAN SZÉKELY'S WOMEN OF EGER}

The scenes depicted in Bertalan Székely's Women of Eger can be traced to 16th century historical sources. The Italian historiographer reporting on the Ottoman siege of Eger in 1552, Ascanio Centorio degli Hortensi presented two episodes to illustrate the valiance and heroism of the women of Eger: one story was about a woman who went on fighting with her husband's sword after he was slain by her side, and the other was of a young girl who hurled the heavy stone that killed her mother at the enemy and killed several Turks. Having become tropes of the bravery of Hungarian women, the two motifs were elaborated in several Hungarian and foreign historical and literary works up to the mid- $19^{\text {th }}$ century, and they appear in book illustrations and art works as well.

As the surviving sketches reveal, Bertalan Székely first experimented with depicting these two episodes. The centre of the final composition features the woman revenging her husband's death, but the story of the mother and daughter was changed: the sketches still show a collapsing mother and a girl throwing the stone, while in the completed painting the two are fighting side by side against the Turks.
The $16-19^{\text {th }}$ century historical and literary sources that emphasize the heroism of the women of Eger demonstrate that there was general agreement in society about women's behavior: women would only leave the private sphere traditionally reserved for them to adopt male behavioral patterns in the public sphere dominated by men in extreme situations, on the battleground. Unlike the image of pugnacious, masculine, sometimes cruel and blood-thirsty women prevalent in the historical sources, Székely's women are more feminine, in accord with the social expectations and concept of the woman in the $19^{\text {th }}$ century.

PAPP Júlia múvészettörténész, MTA Bölcsészettudományi Kutatóközpont, Müvészettörténeti Intézet, H-1014 Budapest, Országház utca 28. / art historian, Hungarian Academy of Sciences, Research Centre for the Humanities, Institute of Art History, pappjulia@arthist.mta.hu

Kulcsszavak: 19. század, festészet, Székely Bertalan, egri nők, toposzkutatás, női vitézség / Keywords: $19^{\text {th }}$ century, painting, Bertalan Székely, women of Eger, trope research, female heroism 